\title{
Transições da Escola para o Trabalho no Brasil: Persistência da Desigualdade e Frustração de Expectativas*
}

Adalberto Cardoso

\section{INTRODUÇÃO}

\begin{abstract}
A o tomar posse em 2003, o presidente Luiz Inácio Lula da Silva anunciou, entre seus planos prioritários de governo, o Programa Nacional de Estímulo ao Primeiro Emprego - PNPE, voltado para uma parcela da população, os jovens de 16 a 24 anos. O programa partia do diagnóstico de que, nessa faixa etária, os jovens enfrentavam problemas específicos para entrar no mercado de trabalho, já que eram responsáveis por $45 \%$ dos 7,7 milhões de desempregados do país ${ }^{1}$. O objetivo da política era estimular as empresas a oferecer vagas para pessoas nessa faixa etária.
\end{abstract}

Embora o programa não seja objeto deste estudo ${ }^{2}$, sua existência denota a percepção, pelo Estado, do desemprego juvenil como problema social emergente passível de (na verdade, demandando) intervenção pública. O Brasil não está sozinho nessa percepção, muito menos na elaboração de políticas desse tipo ${ }^{3}$. O desemprego juvenil tornou-se ques-

\footnotetext{
* Agradeço à Betina Fresneda a sistematização da bibliografia sobre transições da escola para o trabalho e a ela e à Ludmila Mendonça a sistematização dos dados dos censos demográficos de 1970 a 2000. Recebi comentários importantes de Carlos Antônio Costa Ribeiro e Luiz Antonio Machado da Silva; agradeço a ambos. Parte dos argumentos apresentados aqui vieram a público pela primeira vez em um seminário no Observatoire $d u$ Changement, da Sciences-Po, em Paris, onde permaneci por um mês, em 2007, a convite de Edmond Preteceille e Alain Chenu, a quem também devo meus agradecimentos. Foram de especial interesse os comentários de Nicolas Herpin. A responsabilidade pelos equívocos que permanecerem é, obviamente, minha.
}

DADOS - Revista de Ciências Sociais, Rio de Janeiro, Vol. 51, n-3, 2008, pp. 569 a 616. 
tão social de grande envergadura em todos os países do mundo (OECD, 2000). Entre outros fatores, porque, em toda parte, ao diagnóstico da desocupação dos jovens associam-se outros, múltiplos, relacionados, por exemplo, com suas conseqüências sociais mais ou menos duradouras para: os padrões de sociabilidade (com destaque para a violência e os diversos tipos de delinqüência juvenil); a saúde reprodutiva das adolescentes; as oportunidades de vida abertas (ou fechadas) aos jovens no transcurso dessa experiência (o desemprego) que, até há bem pouco tempo, era pensada como intrinsecamente transitória.

De um ponto de vista sociológico, o desemprego dos jovens é especialmente interessante por denotar os mecanismos que delimitam, simbólica e praticamente, os espaços sociais onde se configuram e se negociam as aspirações, os projetos, as oportunidades de vida e, sobretudo, as identidades sociais das pessoas (Dubar, 2005). Na verdade, o desemprego é apenas um dos resultados possíveis de um movimento bem mais amplo que pode ser nomeado de transição da escola para o trabalho, ao qual se costumam associar, por exemplo, idéias como entrada na vida adulta, independência financeira e realização de expectativas existenciais mais profundas - movimento tenso, que mobiliza energias sociais múltiplas e muitas vezes incontroláveis. Ocorre que a divisão social do trabalho confronta, no mercado de trabalho, as demandas das empresas e as preferências, aspirações e qualificações de indivíduos (construídas, no caso dos jovens, sobretudo no sistema educacional) de uma maneira que não pode ser perfeitamente antecipada pelos jovens e suas famílias. Isso porque o tempo de construção e de consolidação da divisão social do trabalho, fruto agregado das decisões empresariais informadas pela busca de lucro, difere da dinâmica familiar, que combina o tempo biológico de gestação e de crescimento dos filhos com o tempo social de construção e de reprodução das instituições, tais como o sistema educacional ${ }^{4}$. Não há nenhuma razão para imaginar que o encontro dessas lógicas distintas produzirá eficiência de mercado ou emprego para todos; tampouco há razão para imaginar que, mesmo havendo ocupação para todos, as pessoas encontrarão os empregos que procuram ou aqueles para os quais se qualificaram no sistema educacional ou vocacional. Dessa perspectiva, a transição da escola para o trabalho é um daqueles processos que revelam a constituição mais profunda da sociedade enquanto estrutura de posições e de oportunidades abertas (ou fechadas) aos indivíduos que a constituem. 
O objetivo deste estudo é analisar como as mudanças na estrutura econômica e nos mercados de trabalho assentaram as bases sobre as quais se edificaram padrões de transição da escola para o trabalho de jovens de ambos os sexos no Brasil, traçando um quadro de longo curso a partir do destino de jovens nascidos de 1948 em diante ${ }^{5}$. Tomam-se por referência os dados dos censos demográficos desde 1970 para sustentar a idéia de que, no Brasil, se configurou um padrão desenvolvimentista de percurso social dos jovens marcado por diminuta importância da educação na configuração de suas oportunidades iniciais de vida, ao menos para a maioria deles, e até muito longe no processo de mudança estrutural por que passou o país desde 1940. Esse padrão pode ser distinguido de outro, que denominarei padrão fordista de transição, típico dos países do capitalismo avançado e caracterizado por forte controle, por parte das famílias e do Estado, dos processos gerais de qualificação para o trabalho, nos quais a escola teve lugar central, sendo o principal elemento de mobilidade social e de geração de oportunidades de vida.

Ambos os padrões entraram em crise nos últimos vinte anos. O que caracteriza o mundo contemporâneo é o fato de o desemprego juvenil retardar as trajetórias dos jovens, empurrando o emprego para cada vez mais tarde na biografia dos indivíduos, enfraquecendo com isso a coincidência entre vida adulta e independência financeira, com esta a responsabilidade pelo provimento de si e de sua própria família. Com isso, a débâcle do desenvolvimentismo, iniciado na década de 1990 e ainda em consolidação, não significou o fim da precariedade do processo de transição da escola para o trabalho. Ao contrário, aumentou, e muito, as incertezas dos jovens quanto a seu lugar na ordem social. A questão, pois, não é meramente econômica. No tratamento da transição da escola para o trabalho, estão em causa os processos mais gerais de construção de identidades sociais e de delimitação de oportunidades de vida de indivíduos e coletividades.

O texto está dividido em três seções, além desta introdução. Inicio pela descrição das mudanças estruturais por que passou a sociedade brasileira entre 1940 e 2000 e seus efeitos sobre os mercados de trabalho. Traço um quadro de fatos estilizados do processo brasileiro de desenvolvimento, em respaldo ao que se apresenta na seção seguinte, isto é, a estrutura e a dinâmica do padrão desenvolvimentista de transição da escola para o trabalho. Com base nos dados dos censos demográficos de 1970 a 2000, mostro que o padrão de acesso ao trabalho apresentou grande inércia estrutural, rompida apenas nos anos 1990, em um duplo 
movimento: de um lado ocorre o aumento da importância da educação como mecanismo de inserção ocupacional; de outro, a expansão do sistema educacional reduz o valor das credenciais educacionais de todos os segmentos. Na conclusão, retomo o argumento central salientando as diversas faces do rompimento do padrão desenvolvimentista de transição da escola para o trabalho e suas conseqüências para as oportunidades de vida dos jovens no país.

\section{MUDANÇA ESTRUTURAL}

Entre 1940 e 1980, o Brasil viveu um processo de profunda mudança estrutural, fruto de um padrão de crescimento econômico que se convencionou denominar desenvolvimentista ${ }^{6}$. Dirigido e financiado pelo Estado em associação com capitais nacionais e estrangeiros, em conjunto com o fechamento do mercado interno à competição externa, aquele padrão transformou o país eminentemente agrário do início do período na oitava economia do mundo, com um Produto Interno Bruto - PIB de 1,3 trilhão de reais em 1980 (em valores de 2006; ver Tabela 17) evolução impressionante. O salto de 1940 a 1950 foi de 77\%; de 1950 a 1960, 104\%; na década seguinte, 82\%; e, por fim, entre 1970 e 1980, de 129\%. O PIB de 1980, pois, era quinze vezes maior do que o de 1940, um crescimento vertiginoso que não teve equivalente no mundo ociden$\mathrm{tal}^{8}$. O crescimento da riqueza foi muito superior ao populacional, e com isso o PIB per capita foi multiplicado por cinco em quarenta anos, o que quer dizer que, em média, a renda nacional por habitante dobrou a cada dez anos.

Nos anos 1980, esse padrão de crescimento foi "ferido de morte". O país não deixou de crescer, mas a taxa de expansão foi pequena em comparação com o crescimento populacional, o que ocasionou, de um lado, a queda da renda per capita, que só retornaria aos patamares de 1980 perto do ano 2000; de outro lado, um aumento expressivo da concentração de renda 9 .

O aumento da riqueza até 1980 foi fruto de uma mudança sem precedentes na estrutura produtiva do país. Em 1950, ainda que o comércio e os serviços, atividades urbanas por excelência, já respondessem por $50 \%$ do PIB, a agropecuária era a segunda maior responsável pela renda total, um pouco à frente da indústria (aqui englobando indústrias extrativas, de transformação e de construção civil; ver Tabela 2). Em 1980, a indústria já produzia $44 \%$ da riqueza total contra $11 \%$ da agri- 
Tabela 1

PIB Real e PIB per capita - Brasil

(1940-2000)

\begin{tabular}{l|c|c|c|c}
\hline Anos & $\begin{array}{c}\text { PIB Real } \\
\text { (Valores em R\$ de 2006) }\end{array}$ & $\begin{array}{c}\text { Evolução } \\
\mathbf{( 1 9 4 0 = 1 0 0 )}\end{array}$ & $\begin{array}{c}\text { PIB per capita } \\
\text { (em R\$ de 2006) }\end{array}$ & Evolução \\
\hline 1940 & 86.963 .600 .000 & 100 & 2.110 & 100 \\
1950 & 154.207 .420 .000 & 177 & 2.970 & 141 \\
1960 & 314.387 .540 .000 & 362 & 4.490 & 213 \\
1970 & 572.121 .820 .000 & 658 & 6.140 & 291 \\
1980 & 1.308 .766 .850 .000 & 1.505 & 11.040 & 523 \\
\hline 1990 & 1.530 .053 .280 .000 & 1.759 & 10.440 & 495 \\
2000 & 1.956 .574 .070 .000 & 2.250 & 11.420 & 541 \\
\hline
\end{tabular}

Fonte: Ipeadata.

Tabela 2

PIB por Setores Econômicos - Brasil

(1950-2000)

\begin{tabular}{l|c|c|c}
\hline Ano & Agropecuária & Indústria & Serviços \\
\hline 1950 & 25,08 & 24,96 & 49,61 \\
1960 & 18,28 & 33,19 & 48,69 \\
1970 & 12,35 & 38,30 & 49,78 \\
1980 & 10,89 & 44,09 & 44,46 \\
\hline 1990 & 8,10 & 38,69 & 52,66 \\
2000 & 5,60 & 27,73 & 66,67 \\
\hline
\end{tabular}

Fonte: IBGE - Departamento de Contas Nacionais.

cultura e 44,5\% dos serviços. Esse quadro de crescimento contínuo da riqueza industrial indicava que, em pouco tempo, o PIB do que então se denominava "setor dinâmico da economia" superaria o de todos os outros setores. A estagnação da década de 1980 impediu esse resultado, e a indústria viu sua participação na riqueza cair bastante nos anos seguintes, retornando, em 2000, a patamares semelhantes aos de 1950. Nesse sentido, o Brasil passou por dois grandes processos de mudança estrutural no período. Primeiro, até 1980, teve-se a perda de centralidade da agricultura como "carro-chefe da economia" e sua substituição pelas atividades tipicamente urbanas, em especial a indústria. A partir de 1980, e muito profundamente nos anos 1990, foi a indústria que perdeu a centralidade que vinha adquirindo pelo processo anterior. Essa perda decorreu não apenas do crescimento maior dos serviços, mas so- 
bretudo da desindustrialização que se seguiu à abertura comercial associada ao câmbio valorizado (a "âncora cambial" do Plano Real), que expôs os produtores nacionais, antes protegidos pelo fechamento da economia típico do desenvolvimentismo, à competição externa. Em conseqüência, o valor real da produção industrial em 2000 era $6 \%$ menor do que aquele de $1980^{10}$.

Acompanhando a mudança de eixo do motor da acumulação, a população migrou intensamente para as cidades no período. Em 1940, aproximadamente dois terços dos brasileiros viviam no campo, e o restante, nas cidades. Quarenta anos depois, a equação se inverte, com dois terços vivendo nas cidades ${ }^{11}$. O processo seguiu seu curso, aprofundando-se nas décadas seguintes, até atingir mais de $80 \%$ de população urbana em 2000.

Nos anos 1960 e 1970, foi grande o debate acadêmico acerca do caráter da industrialização latino-americana de modo geral e da brasileira em particular. Celso Furtado foi um dos primeiros a chamar a atenção para a natureza subordinada do crescimento capitalista na periferia do sistema global. Ao dar substância analítica e conceitual ao subdesenvolvimento, Furtado sugeriu que o capitalismo periférico jamais seria inteiramente inclusivo, porque não geraria seu próprio progresso técnico, estando condenado a importar tecnologia que, no Brasil, teria a função de poupadora de mão-de-obra. Como a tecnologia importada teria como efeito aumentar sobremaneira a produtividade do trabalho, o produto industrial cresceria muito mais do que o emprego, resultando em crescente concentração de renda ${ }^{12}$. Com isso, o mercado interno cresceria muito menos do que o produto, limitando as possibilidades de expansão do sistema. Mais ainda, os países periféricos jamais atingiriam o padrão de desenvolvimento dos países centrais, uma vez que os desníveis de produtividade tenderiam a aumentar em virtude de a industrialização por substituição de importações apoiar-se em mercados pequenos ${ }^{13}$.

Nesse sentido, embora a indústria tenha ganhado prevalência na acumulação capitalista brasileira durante o desenvolvimentismo, o emprego no setor foi, em termos proporcionais, sempre inferior à riqueza produzida. Em 1980, quando era responsável por 44\% do PIB, o setor industrial empregava apenas 25\% dos brasileiros (35\% do emprego urbano total). Com isso, a razão entre participação no PIB e no emprego foi sempre muito alta no caso da indústria se comparada às outras atividades urbanas em seu conjunto (aqui agrupadas na categoria servi- 
ços), algo que só se rompeu, uma vez mais, na década de 1990 (ver as duas últimas linhas da Tabela 3).

Tabela 3

População Economicamente Ativa segundo os Ramos de Atividade - Brasil (1940-2000)

\begin{tabular}{|c|c|c|c|c|c|c|c|}
\hline \multirow[b]{2}{*}{ Setores } & \multicolumn{7}{|c|}{ População de 10 Anos e Mais } \\
\hline & 1940 & 1950 & 1960 & 1970 & 1980 & 1990 & 2000 \\
\hline $\begin{array}{l}\text { População Economi- } \\
\text { camente Ativa }\end{array}$ & 14.758 .598 & 17.117 .362 & 22.6512 .63 & 29.557 .224 & 43.235 .712 & 59.680 .271 & 65.629 .892 \\
\hline $\begin{array}{l}\text { Agricultura, pecuária, } \\
\text { silvicultura, extração } \\
\text { vegetal, caça e pesca }\end{array}$ & 65,9 & 59,91 & 53,7 & 44,29 & 29,28 & 20,1 & 17,71 \\
\hline Atividades industriais & 10,29 & 13,71 & 13,08 & 17,92 & 24,92 & 21,9 & 19,18 \\
\hline $\begin{array}{l}\text { Comércio de } \\
\text { mercadorias }\end{array}$ & 5,08 & 5,6 & 6,71 & 7,66 & 9,34 & 13,7 & 13,63 \\
\hline Prestação de serviços & 17,25 & 19,37 & 22,88 & 25,36 & 31,27 & 41,6 & 41,19 \\
\hline Outras atividades & 1,49 & 1,41 & 3,63 & 4,78 & 5,18 & 2,9 & 8,30 \\
\hline $\begin{array}{l}\text { Razão entre participa- } \\
\text { ção no PIB e no em- } \\
\text { prego por parte da in- } \\
\text { dústria }\end{array}$ & & 1,8 & 2,5 & 2,1 & 1,8 & 1,8 & 1,4 \\
\hline $\begin{array}{l}\text { Idem serviços (soman- } \\
\text { do comércio) }\end{array}$ & & 2,0 & 1,6 & 1,5 & 1,1 & 1,0 & 1,2 \\
\hline
\end{tabular}

Fontes: IBGE: Anuários Estatísticos do Brasil (vários anos); PNAD (1990); Censo Demográfico (2000).

Urbanização, nesse sentido, nunca foi sinônimo de industrialização do emprego, nem mesmo no auge do desenvolvimentismo ${ }^{14}$. Acorreram para as cidades levas crescentes de migrantes do campo, sem que o setor que gerava as melhores ocupações (no âmbito privado) fosse capaz de absorvê-las. Nesse quadro, o crescimento econômico produziu riqueza crescente (o PIB multiplicou-se por quinze e a renda per capita por cinco, até 1980, como já visto neste artigo), mas o fez de forma altamente concentrada. Com isso a pobreza reduziu-se muito lentamente. Em 1970, a proporção de pobres no país era de $68,4 \%$ da população. Nas metrópoles, a taxa era de 53,2\% e de $65,3 \%$ no Brasil urbano extrametropolitano. Esses valores caíram bastante ao longo dos anos 1970, fruto do enorme crescimento econômico e industrial da década, de tal modo que, em 1980, os pobres eram 33\% dos habitantes das cidades menores e $27 \%$ dos habitantes das metrópoles. Esse patamar, porém, se revelaria uma barreira, já que nos anos seguintes a proporção se manteria inalterada ou aumentaria, conforme as conjunturas (Rocha, 
2003:83). Além disso, os números permaneceram portentosos. No início da década de 1980, 50 milhões de brasileiros viviam em domicílios pobres (isto é, com renda per capita inferior à linha de pobreza), subindo para 59 milhões em 1983, no ápice da recessão que assolou o país no início dessa década. Em 1999, eles ainda eram 56 milhões ${ }^{15}$.

Por outro lado, ainda que a pobreza tenha caído na década de 1970, a renda do trabalho urbano permaneceu muito baixa no Brasil ao longo de todo o período descrito aqui. O salário mínimo real médio, que por décadas só teve vigência para trabalhadores urbanos do setor formal da economia, caiu constantemente até 1952, chegando a valer menos de $\mathrm{R} \$ 150$ (em valores de junho de 2007). Nos anos seguintes (coincidentes com o segundo governo Vargas e com as gestões de Juscelino Kubitschek, Jânio Quadros e João Goulart), esse valor oscilou entre $\mathrm{R} \$ 400$ e $\mathrm{R} \$ 600$, para retornar ao patamar médio entre $\mathrm{R} \$ 300$ e $\mathrm{R} \$ 330$ até perto do final da década de 1980. Nos anos 1990, o valor real do mínimo voltou a cair, retomando o crescimento a partir de 1995 (cf. Gráfico 1; a linha contínua representa a média móvel de doze meses). Importante

Gráfico 1

Salário Mínimo Real Mensal - Brasil: 1944-2000 (preços de junho de 2007)

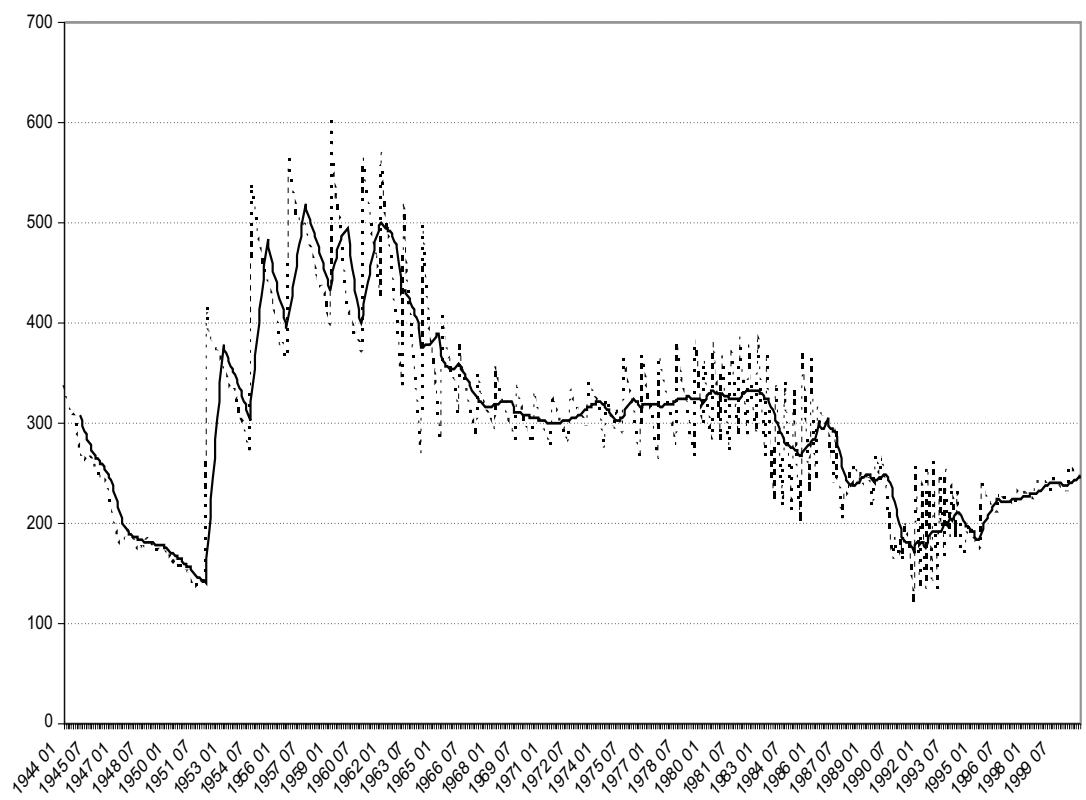

Fonte: Ipeadata (www.ipeadata.gov.br/ipeaweb.dll/ipeadata?4794734). 
salientar que o salário mínimo era e é arbitrado pelo Estado, sendo a principal política de renda no país até muito recentemente ${ }^{16}$.

Ademais, a renda real da população urbana não mudou muito entre 1960 e 1980. Considerando os ocupados em atividades não-agrícolas no Brasil, 52,4\% ganhavam um salário mínimo ou menos em setembro de 1960, data de referência do Censo Demográfico. Nesse mesmo mês, o salário mínimo era de $\mathrm{R} \$ 389$, a preços de junho de 2007. Até dois salários (R $\$ 778$ ), tínhamos 75,7\% dos ocupados urbanos. Em 1970, esses valores sofreram mudança, mas na direção contrária ao esperado de um processo de urbanização que representasse melhoria de vida para a maioria dos migrantes. Os que ganhavam até um e até dois salários mínimos eram 50,7\% e 73,9\%, respectivamente, praticamente a mesma proporção de dez anos antes ${ }^{17}$. Ocorre, porém, que esses dados escondem uma perda real de $22 \%$ no valor do salário mínimo, que valia $\mathrm{R} \$ 303$ na data do Censo de 1970. Isto é, $74 \%$ da população empregada ganhava $R \$ 606$ ou menos. A primeira trintena do processo de urbanização significou perda de renda para os trabalhadores urbanos.

Esse panorama mudaria na década seguinte, quando a proporção que ganhava um salário mínimo ou menos caiu substancialmente para $24,7 \%$ dos trabalhadores urbanos. Contudo, até dois salários mínimos (ou perto de $\mathrm{R} \$ 620$, a preços de 2007) tínhamos 56,2\% da população empregada nas cidades. Até três mínimos (aproximadamente R\$930), $71 \%$. Ou seja, a renda máxima de $71 \%$ dos trabalhadores do país em 1980 era apenas $21 \%$ maior do que a de $75,7 \%$ dos ocupados de $1960^{18}$. Houve melhoria, mas ela foi muito pequena e não se sustentou na chamada "década perdida". Em 1990, mais de 72\% dos ocupados nas cidades ganhavam o equivalente a $\mathrm{R} \$ 890$ por mês ou menos, segundo dados da Pesquisa Nacional por Amostra de Domicílios - PNAD ${ }^{19}$. Ainda em 2000, os mesmos $72 \%$ da população urbana ganhavam menos de $\mathrm{R} \$ 900$ por mês ${ }^{20}$. A baixa renda irmanou ocupados rurais e citadinos ao longo da história de mudança estrutural do país, e isso até muito recentemente.

Em conseqüência, isto é, considerando-se que o salário médio real da população ocupada se manteve em patamares rasteiros, a mobilidade social medida em termos da renda foi bastante limitada ${ }^{21}$. Tome-se a trajetória dos migrantes em 1976. Se ordenarmos as ocupações dos empregados nesse ano em termos da renda média de cada ocupação, e definirmos como ocupações de baixa renda aquelas com remuneração mé- 
dia igual ou inferior a $60 \%$ da renda média de todas as ocupações ${ }^{22}$, e compararmos com a ocupação anterior do migrante (isto é, a ocupação que ele ou ela possuía antes de migrar), temos que $61 \%$ dos homens e $87 \%$ das mulheres que migraram e encontraram outro emprego o fizeram de uma ocupação mal remunerada para outra. Verdade que 39\% dos homens melhoraram sua posição, mas uma proporção significativa desses últimos migrou para ocupações muito próximas da fronteira de baixa renda.

Tabela 4

Mobilidade entre Ocupações de Baixa Renda no Brasil

(1976)

\begin{tabular}{l|c|c|c|c}
\hline \multirow{2}{*}{ Sexo } & \multirow{2}{*}{ Baixa Renda Anterior } & \multicolumn{2}{|c|}{ Baixa Renda Atual } & \multirow{2}{*}{ Não } \\
\cline { 3 - 4 } Masculino & Não & $89,90 \%$ & Sim & N \\
\cline { 3 - 4 } & Sim & $39,10 \%$ & $\mathbf{6 0 , 9 0 \%}$ & 3.255 .461 \\
& Subtotal & $55,40 \%$ & $44,60 \%$ & 10.143 .480 .019 \\
\hline Feminino & Não & $84,50 \%$ & $15,50 \%$ & 517.697 \\
& Sim & $13,40 \%$ & $\mathbf{8 6 , 6 0 \%}$ & 1.761 .153 \\
& Subtotal & $29,50 \%$ & $70,50 \%$ & 2.278 .850 \\
\hline
\end{tabular}

Fonte: IBGE, microdados da PNAD (1976).

Por outro lado, considerando-se o ano de 1982 e comparando-se a renda da ocupação do filho que era chefe de família com a renda da ocupação de seu pai, tem-se que, para $54 \%$ dos pais que tinham ocupações de baixa renda quando seus filhos tinham 15 anos, estes também estavam empregados em ocupações desse tipo no momento da pesquisa da $\mathrm{PNAD}^{23}$. Uma vez mais, dos $46 \%$ que haviam melhorado de posição, perto de um quarto estava em ocupações fronteiriças à linha definidora de baixa renda. Os dados para 1996, quando nova rodada da PNAD mediu a mobilidade social, eram muito semelhantes ${ }^{24}$.

Assim, é verdade que a urbanização significou melhoria de vida para uma parte significativa da população que abandonou o campo em fuga da pobreza, das mudanças tecnológicas, das secas ou dos movimentos de concentração fundiária. Contudo, a combinação de políticas salariais restritivas, que mantiveram o salário mínimo abaixo das necessidades básicas da população, com oferta abundante de mão-de-obra despossuída e pouco qualificada trazida às cidades pela intensa migração interna, contribuiu para depreciar a renda do trabalho. Em conseqüên- 
cia, a população vinda do campo estabeleceu-se nas cidades em patamares muito baixos de renda, processo cuja linha ascendente iniciada nos anos 1970 foi interrompida na década de 1980 em razão da crise geral que afetou a economia brasileira.

No processo de mudança estrutural em discussão, a educação sempre foi um limite à melhoria das condições de vida da maioria da população. É claro que houve intensa mobilidade educacional ascendente de uma geração para outra, maior a cada nova coorte de nascimento. Em 1982, quando a PNAD colheu dados que permitiam comparar a escolaridade do chefe da família pesquisada com a de seus pais, descobriu-se que metade dos filhos tinham atingido nível escolar superior ao dos pais. Aproximadamente um terço estava no mesmo nível educacional, e $19 \%$ tinham menos escolaridade. Esses valores eram melhores quanto mais jovens eram os chefes, isto é, quanto mais se aprofundou o processo de urbanização, maior foi a mobilidade escolar ascendente (cf. Tabela 5). Para os filhos de pais que tiveram ocupação no campo, a taxa era ainda maior - 58\% melhoraram sua escolaridade. Em 1996, a mobilidade escolar ascendente foi real para $57 \%$ dos chefes de família, e de $67 \%$ para os que tinham idade entre 26 e 35 anos. Entre os chefes de 1996 com pais de origem rural, a mobilidade ascendente foi de $62 \%$.

Tabela 5

Mobilidade Escolar dos Chefes de Família, em Relação a seus Pais, por Faixas Etárias - Brasil

(1982 e 1996)

\begin{tabular}{l|c|c|c|c}
\hline \multirow{2}{*}{$\begin{array}{l}\text { Faixas de Idade } \\
\text { do Chefe }\end{array}$} & Descendente & Imobilidade & Ascendente & N \\
\cline { 2 - 4 } & \multicolumn{3}{|c|}{$\mathbf{1 9 8 2}$} \\
\hline Até 25 anos & $15,0 \%$ & $23,9 \%$ & $61,1 \%$ & 5.937 .115 \\
\hline 26 a 35 anos & $15,2 \%$ & $25,6 \%$ & $59,2 \%$ & 13.068 .761 \\
\hline 36 anos ou mais & $21,5 \%$ & $36,2 \%$ & $42,3 \%$ & 27.229 .663 \\
\hline Total & $18,9 \%$ & $31,6 \%$ & $49,5 \%$ & 46.235 .539 \\
\hline 10 a 25 anos & $19,8 \%$ & $15,0 \%$ & $65,3 \%$ & 6.119 .946 \\
\hline 26 a 35 anos & $17,2 \%$ & $15,9 \%$ & $67,0 \%$ & 16.149 .859 \\
\hline 36 anos ou mais & $19,0 \%$ & $28,9 \%$ & $52,1 \%$ & 40.984 .443 \\
\hline Total & $18,6 \%$ & $24,2 \%$ & $57,2 \%$ & 63.254 .248 \\
\hline
\end{tabular}

Fonte: IBGE, microdados da PNAD (1982; 1996). 
Se houve mobilidade educacional ascendente, ela ocorreu a partir de um patamar muito baixo de escolaridade geral. Além disso, uma grande parte dos membros das primeiras gerações de migrantes transferiu à maioria de seus filhos padrões educacionais apenas levemente descolados dos de origem. Por exemplo, em 1982, 53\% dos pais analfabetos tinham "transferido" seu analfabetismo aos filhos. Em 1996, a taxa era de $37 \%$. Para os pais apenas alfabetizados em 1982, 77\% tiveram filhos que atingiram até quatro anos de escolaridade, e $66 \%$ dos que não chegaram a completar o ensino elementar (correspondente a cinco anos de escolaridade em 1970) tampouco permitiram que seus filhos ultrapassassem essa barreira. Em 1996, as taxas eram 70\% e 59\%, respectivamente. Portanto, houve ascensão, mas muito lenta e acompanhada de substancial permanência entre uma geração e outra, o que contribuiu para manter sempre baixa a escolaridade global.

Entre os ocupados, isso era ainda mais flagrante. Em 1970, nada menos do que dois terços da População Economicamente Ativa - PEA tinham até três anos de escolaridade. No campo, essa proporção era de $90 \%$ contra $52 \%$ dos trabalhadores industriais e $60 \%$ daqueles na prestação de servi$c_{c}{ }^{25}$. Se considerarmos aqueles com até cinco anos de escolaridade, tínhamos $99 \%, 84 \%$ e $91 \%$ dos ocupados, respectivamente (75\% nas atividades urbanas em seu conjunto). Em 1980, esse quadro mudara, mas a escolarização da PEA permanecia muito baixa. Entre os trabalhadores industriais, tomando-se apenas a indústria de transformação, 60\% tinham até quatro anos de estudo (equivalente ao primário naquele ano). Na construção civil, a taxa era de $81 \%$; nos serviços, $68 \%$; no comércio, $51 \%$. Nas atividades urbanas, 57\% dos trabalhadores tinham até quatro anos de estudo, e 12,5\% eram analfabetos (no campo, 52\% da população empregada era analfabeta em 1980) ${ }^{26}$. Durante o desenvolvimentismo, houve melhoria da escolaridade da PEA, mas ela permaneceu em patamares médios iguais ou inferiores a quatro anos de estudo.

Isso quer dizer que o processo de inclusão escolar da população foi muito lento. Em um primeiro momento, a migração do campo para a cidade não resultou em mobilidade educacional de monta, o que significa dizer que a mobilidade social não parece ter encontrado na educação seu principal motor. A mudança mais profunda, na verdade, referiu-se à drástica redução do analfabetismo entre os trabalhadores urbanos, em comparação com os trabalhadores rurais. Apenas no raiar da década de 1980, a mudança de patamar seria anunciada, com o iní- 
cio do rompimento da barreira dos quatro anos de escolaridade para a maioria dos trabalhadores urbanos - processo ainda em curso. Em 2001, portanto, transcorridos mais vinte anos, $29 \%$ dos trabalhadores urbanos tinham quatro anos ou menos de estudo e $36 \%$ tinham onze anos ou mais ${ }^{27}$.

O painel traçado aqui, portanto, é de grandes mudanças estruturais na economia, acompanhado de apreciável inércia social no que diz respeito aos padrões de acesso à renda, inclusive sua distribuição desigual ${ }^{28}$. Em paralelo, o padrão de inclusão escolar dos que migraram do campo para a cidade, incluindo seus filhos, também foi muito lento. A análise sugere que a inércia decorreu do fato de o desenvolvimentismo ter gerado riqueza, mas de forma concentradora de renda, aumentando as desigualdades sociais de uma maneira geral e mantendo sempre muito altos os patamares de pobreza.

É contra esse pano de fundo que se desenrolaram as transições da escola para o trabalho dos jovens brasileiros ao longo das décadas. Os censos demográficos de 1970 e os subseqüentes permitem captar os percursos desses jovens, e é a isso que me proponho em seguida. Analiso as coortes de nascidos entre 1948-1960, 1958-1970, 1969-1981 e 19781990, tentando desenhar, nos movimentos de saída da escola e de entrada no mercado de trabalho, o que chamei de padrão desenvolvimentista de transição escola-trabalho.

\section{Modelos de Transição}

Iniciei este estudo chamando a atenção para uma política pública de governo que elegeu o desemprego juvenil como problemático. Mais do que simples estatística, o desemprego expressa a crescente dificuldade de inserção profissional dos jovens de todas as classes sociais, resultante de mudanças profundas na configuração dos mercados de trabalho, por sua vez produto dos múltiplos efeitos da revolução por que passou a divisão internacional do trabalho no mundo globalizado. $\mathrm{Na}$ verdade, a identificação do desemprego juvenil como problema social a ser combatido é devedora de uma concepção de trajetória de vida típica do capitalismo organizado, ou do Estado de Bem-Estar Social, segundo a qual a entrada na fase adulta estava associada à obtenção de um emprego, em uma seqüência de eventos que conectava, de forma mais ou menos estruturada, nascimento $\rightarrow$ socialização em família $\rightarrow$ entrada na escola $\rightarrow$ entrada no mercado de trabalho, essa última coin- 
cidindo, no mais das vezes, com a constituição, pelo jovem, de sua própria família ${ }^{29}$. Nesse modelo, o acesso a um emprego era decorrência natural do investimento das famílias na formação de seus filhos, em um mundo em que a relativa previsibilidade da estrutura ocupacional (Pinçon, 1987; Castel, 1998) permitia um planejamento mais ou menos bem informado, pelas famílias, das carreiras de seus membros ${ }^{30}$. Mais ainda, no capitalismo ocidental, esse planejamento encontrou respaldo no pleno emprego como política estatal deliberada, o Estado de Bem-Estar Social emergindo também como guardião das trajetórias estruturadas de vida, nas quais a transição da escola para o trabalho se dava de forma bastante regulada e protegida ${ }^{31}$. Com base nisso, parece plausível sustentar a idéia de que, ao menos nos trinta anos posteriores à Segunda Guerra, se consolidou, nos países centrais do capitalismo, um padrão fordista de trajetória de vida ${ }^{32}$, no qual a transição da escola para o trabalho era o principal marcador de entrada na vida adulta.

É claro que os arranjos institucionais que condicionaram essa transição variaram significativamente de um país para outro (Rosenbaum e Kariya, 1989; Kerckhoff, 1990; Müller e Gangl, 2003). No Japão, por exemplo, eram (e em grande medida ainda são) fortes as ligações institucionais entre empresas, escolas e universidades. O sistema educacional recomendava estudantes a empregadores específicos, com os quais mantinham estreitas relações institucionais e econômicas, de tal modo que o desempenho educacional tinha impacto decisivo sobre as chances de carreira dos jovens. Tratava-se de caso extremo de regime de transição escola-trabalho altamente regulado e pouco competitivo, que teve na Alemanha um exemplo semelhante, mas bem menos fechado. O sistema alemão mesclava (e ainda mescla) educação geral com treinamento no ensino médio, desenvolvendo habilidades específicas para determinadas ocupações, ou seja, o treinamento se dava institucionalmente por meio do ensino vocacional (técnico) baseado na escola ou em programas de aprendizagem nos próprios locais de trabalho, regulados pelo Estado ${ }^{33}$. Os Estados Unidos, ao contrário, sempre foram um caso típico de sistema aberto, no qual as chances no mercado de trabalho se definem por mecanismos competitivos, ainda que hierarquias do sistema educacional (universidades mais bem qualificadas do que outras, por exemplo) tendam a se transferir para as chances de mercado das pessoas ${ }^{34}$. A França é um caso semelhante, combinando regulamentação extensa das profissões com formação relativamente aberta, em um sistema educacional altamente hierar- 
quizado em termos de qualidade e barreiras à entrada (Bourdieu e Passeron, 1974; Müller e Gangl, 2003).

Essa variabilidade entre países decorre de que tanto o desenho institucional quanto o padrão de relações entre os sistemas nacionais de treinamento e educação, de um lado, e a dinâmica do mercado de trabalho, de outro, resultaram de múltiplas interações entre interesses diversos no decorrer de longos períodos de tempo, de tal modo que a estrutura das instituições educacionais, os percursos escolares dos alunos, os currículos, as injunções regulatórias impostas pelo Estado, as regras de funcionamento do mercado de trabalho, o papel de organizações coletivas (como sindicatos e organizações profissionais), tudo isso variou intensamente, afetando de forma diversa o percurso educacional e as chances de carreira das pessoas nos diferentes contextos nacionais (Müller e Shavit, 1998:3).

No Brasil, esse padrão fordista de transição da escola para o trabalho não chegou a se configurar plenamente. Em primeiro lugar, porque as taxas de evasão escolar sempre foram muito altas. Durante o desenvolvimentismo, a educação formal nunca foi o principal mecanismo de qualificação para o trabalho, que se deu, tipicamente, nos próprios locais de trabalho ou em instituições como Serviço Nacional de Aprendizagem Industrial - Senai e Serviço Nacional de Aprendizagem Comercial-Senac, que tiveram papel importante na qualificação profissional para o emprego na indústria ou no comércio, por fora do sistema educacional oficial. É verdade que o ensino técnico profissionalizante chegou a ter "um peso não desprezível no nível médio de ensino. No final da década de 1960, aproximadamente um terço das matrículas e conclusões de curso ocorria no ensino técnico" (Hasenbalg e Silva, 2003:149). Contudo, como ilustra o Gráfico 2, na idade-padrão de conclusão do ensino médio (18 anos), metade dos jovens citadinos já havia deixado a escola, a maioria deles para trabalhar (embora não fosse desprezível a taxa dos que deixavam a escola para não fazer nada, isto é, nem trabalhar nem estudar). Se as matrículas no ensino médio ocorriam em proporção não-desprezível, no ensino técnico, a proporção de jovens matriculados era bastante baixa. No campo, a taxa de evasão era ainda maior, com quase $80 \%$ dos jovens fora da escola aos 17 anos de idade. Isto é, os jovens começavam a trabalhar muito cedo. No Gráfico 2 , podemos ver que $43 \%$ daqueles do sexo masculino que viviam nas cidades e tinham 17 anos de idade já estavam trabalhando em 1970 (parte deles trabalhava e estudava), taxa que se elevava a $52 \%$ entre os 


\section{Gráfico 2}

Transição da Escola para o Trabalho no Brasil

Jovens do Sexo Masculino Nascidos entre 1948 e 1960, Situação em 1970

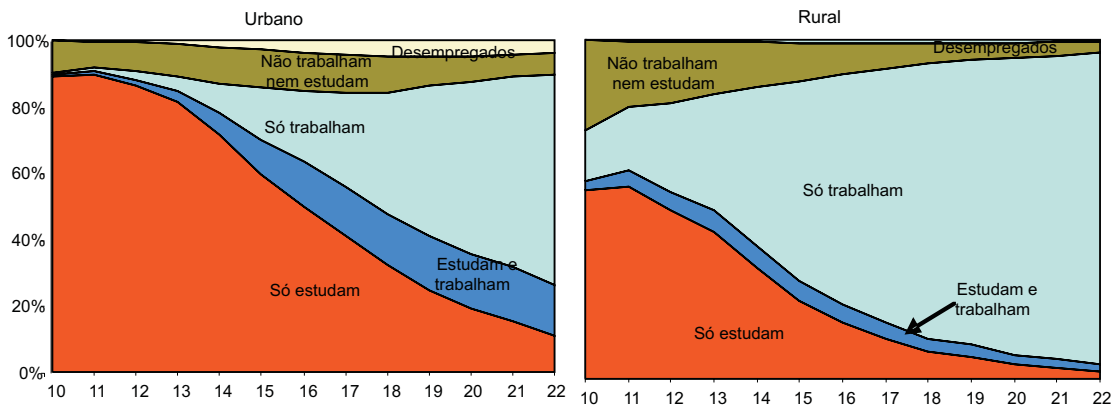

Fonte: IBGE, microdados do Censo Demográfico de 1970.

jovens homens de 18 anos. Entre os habitantes do mundo rural, as proporções eram de $80 \%$ e $85 \%$, respectivamente.

Em segundo lugar, apesar do abandono precoce da escola por proporção significativa dos jovens do sexo masculino, a transição para o trabalho não se dava sem percalços. Ainda que o destino mais provável daqueles que deixavam a escola fosse o mercado de trabalho, este não era o único destino possível. Cerca de $10 \%$ dos jovens citadinos de 10 anos estavam fora da escola em 1970, e destes, $90 \%$ não estavam no mercado de trabalho. Entre os jovens de 15 anos, um terço dos $40 \%$ que não estudavam tampouco estava no mercado de trabalho. No campo, as proporções eram bem menores em termos relativos, mas a taxa de crianças de 10 anos fora da escola e não trabalhando era de 27\% (ou $55 \%$ dos que tinham deixado a escola). Entre os de 15 anos, $11 \%$ não estudavam nem trabalhavam.

Em outras palavras, de modo geral, a relação entre escola e trabalho era intensamente chiástica e simétrica, cada destino sendo excludente em relação ao outro, na maior parte das vezes, e ambos respondendo por cerca de $80 \%$ das probabilidades globais dos jovens de 10 a 22 anos em 1970 (cf. Gráfico 3). No entanto, uma parcela não-desprezível, embora cadente quanto mais velhos os jovens, não participava de nenhum dos dois mundos, principais estruturadores de identidades sociais juvenis no período.

Em terceiro lugar, e talvez o mais importante, ainda que os jovens já tivessem majoritariamente ingressado no mercado de trabalho com cer- 


\section{Gráfico 3}

Relação entre Probabilidade de Estar na Escola ou Trabalhando:

População Jovem Masculina no Campo e na Cidade, Nascida entre 1948 e 1960,

Situação em 1970

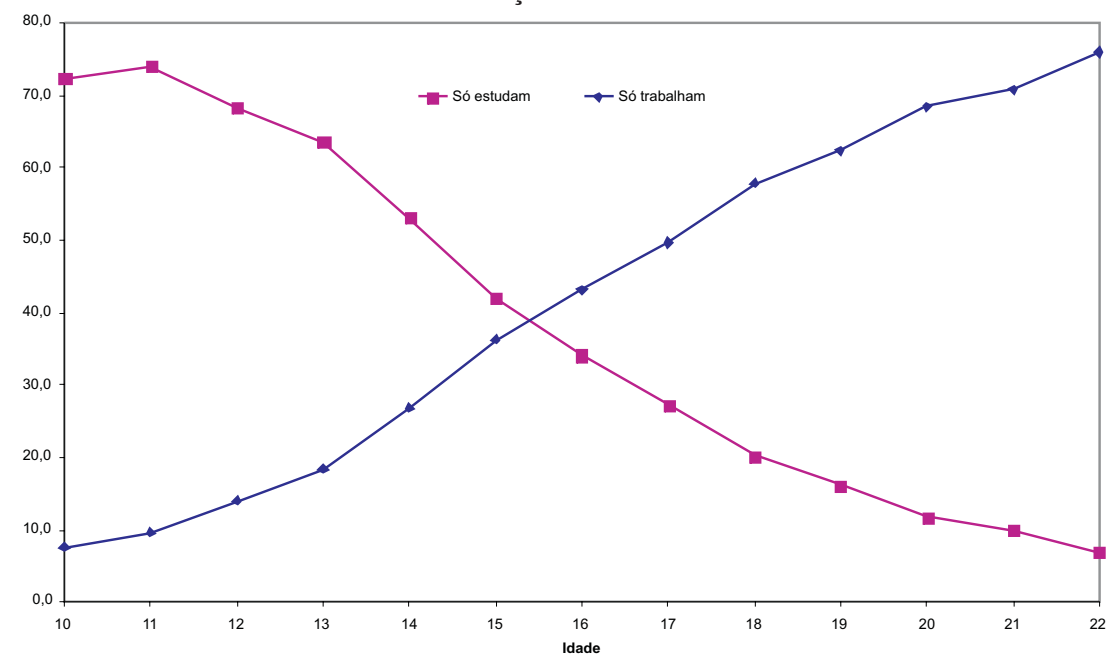

Fonte: IBGE, microdados da amostra de 25\% do Censo Demográfico de 1970.

ca de 22 anos de idade (83\% na cidade e $94 \%$ no campo, em 1970), essa inserção não se deu em condições tipicamente fordistas de trabalho. $\mathrm{O}$ assalariamento urbano nunca foi universal no Brasil ${ }^{35}$. Em 1940, 36,4\% dos ocupados em atividades não-agrícolas eram trabalhadores por conta própria (Prandi, 1978:63). Esse valor ultrapassaria facilmente os $60 \%$ se incluíssemos os ocupados no campo, então o local de emprego e moradia da maioria da população brasileira. Em 1970, os trabalhadores por conta própria eram $20 \%$ dos ocupados nas cidades (ibidem). Somem-se a isso os assalariados sem carteira (para os quais não há dados antes de 1976), e teremos pelo menos metade da população total empregada em ocupações não reguladas pela institucionalidade que ordenava (e ainda ordena) o mercado de trabalho no país, ou seja, a Consolidação das Leis Trabalhistas - CLT. Junto à população jovem a taxa de não-regulação era sem dúvida superior a isso, como veremos mais adiante.

Por fim, esses processos apresentavam grande inércia estrutural. Os censos de 1970 (captando a trajetória de jovens de 10 a 22 anos nascidos entre 1948 e 1960), de 1980 (nascidos entre 1958 e 1970) e de 1991 (nascidos entre 1969 e 1981) registraram poucas mudanças no movimento geral, com leve aumento da proporção de jovens estudando e traba- 
lhando a cada decênio, e com redução da proporção daqueles que não estavam nem na força de trabalho nem na escola. Em 1991, 89\% dos jovens urbanos de 10 anos de idade estudavam; mesma proporção encontrada em 1970. No entanto, em todos os casos, 17 anos configuravam uma fronteira etária que, cruzada, lançava fora da escola pelo menos metade dos jovens urbanos brasileiros do sexo masculino. Para os jovens rurais, a fronteira da expulsão da maioria eram os 13 anos (cf. Gráficos 2, 4 e 5). Isso só mudaria ao longo dos anos 1990.

Em outras palavras, a intensa urbanização descrita anteriormente, que trouxe para as cidades a maioria da população brasileira, só produziria efeitos sensíveis sobre a dinâmica da transição da escola para o traba-

\section{Gráfico 4}

Transição da Escola para o Trabalho no Brasil

Jovens do Sexo Masculino Nascidos entre 1958 e 1970, Situação em 1980

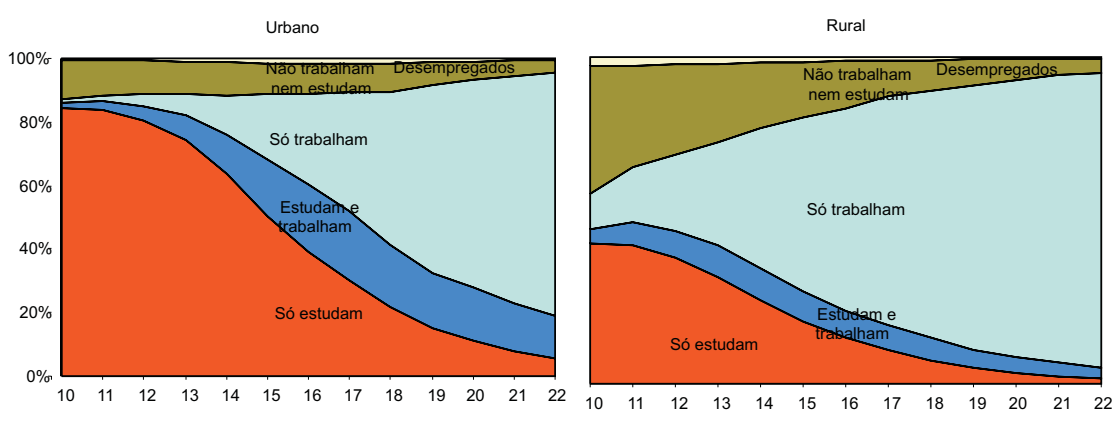

Fonte: IBGE, microdados do Censo Demográfico de 1980.

\section{Gráfico 5}

Transição da Escola para o Trabalho no Brasil

Jovens do Sexo Masculino Nascidos entre 1969 e 1981, Situação em 1991
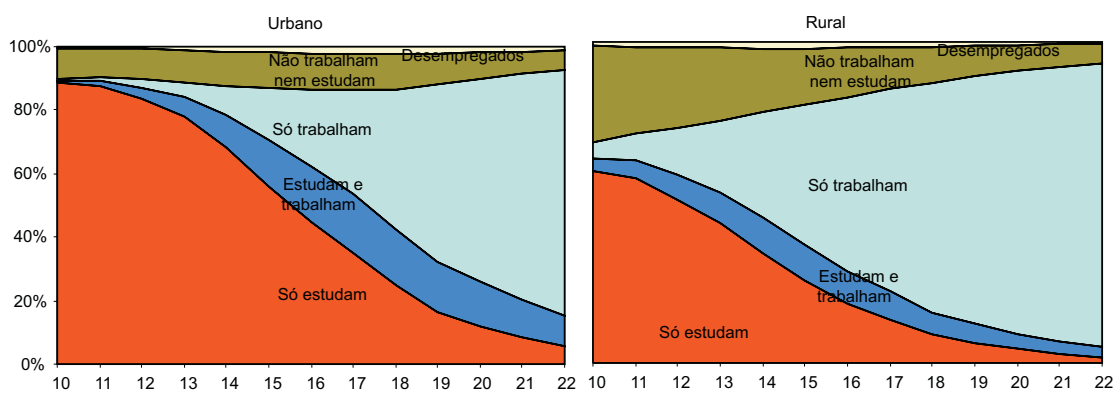

Fonte: IBGE, microdados do Censo Demográfico de 1991. 
lho dos jovens vinte anos depois, como pode ser visto no Gráfico 6. Em termos muito gerais, essa mudança resultou no rompimento da simetria chiástica da relação entre os dois destinos típicos. Sair da escola deixou de significar arrumar um emprego. Primeiro porque, para a proporção crescente dos jovens, emprego e trabalho deixaram de ser alternativas excludentes. Uma proporção cada vez maior deles passou a estudar e trabalhar, e isso tanto no campo quanto na cidade (20\% dos jovens de 16 anos na cidade; $30 \%$ no campo; $22 \%$ e $24 \%$ dos de 18 anos), o que contribuiu para que retardassem a saída da escola. Quase $88 \%$ dos jovens urbanos de 15 anos permaneciam na escola em 2000 (75\% no campo) contra $68 \%$ (e 28\%) em 1980. Em segundo lugar, porque o desemprego, que atingiu 10\% dos jovens de 18 anos em 2000, ganhou relevância como destino provável dos egressos do sistema escolar. Esse fato inaugura um novo cenário na transição, que já não pode ser chamada "da escola para o trabalho". Agora, os jovens transitam da escola para a força de trabalho, não necessariamente empregada, ou para a inatividade pura e simples. De fato, dos jovens urbanos de 17 anos que haviam deixado a escola para ingressar na força de trabalho (26\% do total), metade estava desempregada ou fora da PEA ${ }^{36}$. Entre os de 16 anos, $55 \%$ estavam nessa condição, taxa que chegou a $65 \%$ entre os de 15 anos. Ou seja, quanto mais cedo o jovem urbano deixou a escola em 2000, maior foi a probabilidade de que seu destino fosse o desemprego ou a inatividade. Em 1980, esses valores eram $21,8 \%, 27,5 \%$ e $35,3 \%$, respectivamente.

Em suma, os censos de 1970 e de 1980 captaram a trajetória ascendente do período de industrialização por substituição de importações que,

\section{Gráfico 6}

Transição da Escola para o Trabalho no Brasil

Jovens do Sexo Masculino Nascidos entre 1978 e 1990, Situação em 2000

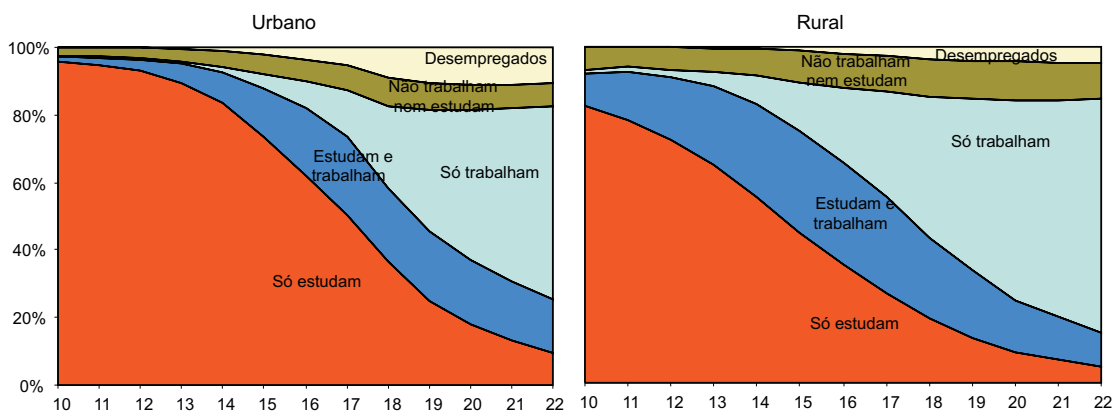

Fonte: IBGE, microdados do Censo Demográfico de 2000. 
do ponto de vista que nos interessa, resultou em mudança estrutural na composição do mercado de trabalho, antes majoritariamente marcado por ocupações agrárias, para uma configuração em que passaram a predominar ocupações dos setores terciários urbanos, com a indústria e a construção civil aparecendo como empregadores minoritários, embora relevantes. Na verdade, ainda que, nesse período, a indústria tenha assumido a dianteira na geração da riqueza, como já visto, o Brasil nunca chegou a ser uma sociedade industrial em termos de emprego $^{37}$, tampouco, como sugerido, uma "sociedade salarial", no sentido de que a maioria de sua população tivesse encontrado emprego assalariado regulado pelo Estado. Bem ao contrário, o emprego gerado nos anos de pico do desenvolvimentismo era de má qualidade, isto é, além de regulado apenas nos setores dinâmicos, marcava-se por alta rotatividade, baixos salários, baixa escolaridade e baixa qualificação.

Esse mercado de trabalho incorporou, de forma também não estruturada, a maioria dos jovens egressos do sistema escolar. Entre 1970 e 1991, pelo menos $90 \%$ dos jovens homens de 22 anos (no campo e na cidade) já trabalhavam. No entanto, segundo a PNAD de 1976, 34\% deles estavam em empregos sem carteira assinada ou ocupados como auxiliares de família sem remuneração, e apenas $50 \%$ eram assalariados com carteira. Entre os jovens de 14 a 17 anos, aquela primeira proporção era de, nada menos, $72 \%$ dos ocupados ${ }^{38}$ (menos de $22 \%$ eram empregados com carteira). Ou seja, até 1991, os jovens entravam muito mais cedo no mercado de trabalho e o faziam em ocupações precárias ou não remuneradas. Esse quadro se agravou nos anos 1990, quando o desemprego foi incorporado ao ambiente de precariedade estrutural, agora em função da reestruturação econômica. A taxa de ocupação dos jovens urbanos de 22 anos que haviam deixado a escola em 2000 não passava de $77 \%$. Para os de 18 anos, esse valor era de $59 \%$, segundo os dados do Censo Demográfico ${ }^{39}$.

Isso quer dizer que o transcurso da escola para o trabalho no Brasil sempre foi inseguro e precário para a maioria dos jovens; insegurança e precariedade aprofundadas nos anos 1990. Em razão da reestruturação econômica desatada pelo programa de ajuste econômico, iniciado em 1994, combinada com a expansão escolar, que reduziu o valor das credenciais educacionais, os jovens passaram a ver suas perspectivas de carreira postergadas para fases mais avançadas do curso de vida ${ }^{40}$. A idéia mesma de uma "carreira para a vida" tornou-se sem sentido no mundo do trabalho flexível, no qual habilidades se tornam rapidamen- 
te obsoletas e a capacidade de os trabalhadores se reciclarem e se adaptarem a novas tarefas torna-se ativo cada vez mais valorizado. A esse propósito, Camarano et alii (2001:34) concluem sobre o final dos anos 1990:

O mercado de trabalho encontrado pelos jovens de hoje é muito diferente do mercado encontrado pelos seus pais. Os contratos de trabalho são piores, expandiram-se os contratos temporários e a informalidade aumentou. De forma geral, os jovens de hoje recebem salários mais baixos e estão mais desprotegidos, não contando com o acesso aos benefícios de uma rede de proteção social - como, por exemplo, os benefícios previdenciários, de saúde e seguro-desemprego. Por outro lado, observam-se crescentes obstáculos para a obtenção do primeiro emprego.

A década de 1990, aparentemente, caracterizou-se pelo rompimento do padrão desenvolvimentista de transição para o trabalho. Antes de aprofundar esse ponto, é preciso fazer uma ressalva importante.

\section{Uma Contrapartida: Trajetórias de Mulheres}

O padrão fordista de transição da escola para o trabalho descrito antes, com o Estado de Bem-Estar Social secundando as opções de indivíduos e famílias no curso de suas vidas, baseou-se, tipicamente, nas trajetórias masculinas nos países centrais. Ele não descreve adequadamente as trajetórias de vida, estudo e trabalho das mulheres jovens naqueles países. Em primeiro lugar, porque, a partir dos anos 1950, as mulheres passaram a permanecer na escola por mais tempo, igualando-se aos homens e em seguida ultrapassando-os tanto em termos do tempo de permanência quanto do desempenho escolar (Shavit e Blossfeld, 1993). Esse padrão representou uma mudança importante em relação ao cenário anterior à Segunda Guerra, quando as mulheres permaneciam por bem menos tempo na escola do que os homens, sobretudo porque participavam pouco do mercado de trabalho, e a educação como aspecto da qualificação para trabalhar não fazia o mesmo sentido para as mulheres e para os homens. Em segundo lugar, porque, apesar da mudança em relação ao início do século, o destino típico das mulheres, uma vez abandonada ou terminada a escola (e ao menos até o início dos anos 1970 na maioria dos países do capitalismo avançado), ainda era a inatividade. Proporção não-desprezível deixava os estudos para constituir família, e das que não o faziam boa parte permanecia na casa dos pais à espera desse desfecho padrão ${ }^{41}$. 
O Brasil não foi diferente nesse pormenor. Em 1970, embora as mulheres fossem metade da população, eram apenas $21 \%$ da PEA (18\% em $1960^{42}$ ). A taxa de atividade das jovens de 22 anos era de $28,5 \%$ em 1970, e $64 \%$ delas não estudavam nem trabalhavam. No entanto, como mostra o conjunto de gráficos a seguir, ao contrário do que se passou nos países mais ricos a partir dos anos 1950, a taxa de participação na escola por parte das mulheres foi quase sempre menor quando comparada à dos homens, se somarmos a proporção que estava apenas na escola e a que estava estudando e trabalhando. Isso só mudaria durante os anos 1990, de tal modo que, em 2000, ao menos para quem tinha até 17 anos de idade, a taxa de freqüência escolar delas superava a deles, se bem que muito ligeiramente ${ }^{43}$. Contudo, para as mulheres, a inércia estrutural geral foi bem menor do que para os membros do sexo oposto, tal como ocorreu nos países centrais. Ainda que seja lento o processo de aumento da participação escolar feminina ${ }^{44}$, a proporção das que não trabalhavam nem estudavam caiu bastante a cada década. Tomando-se, por exemplo, as mulheres de 22 anos em 1970, 64\% não trabalhavam nem estudavam, taxa que caíra para 55\% em 1980, 47\% em 1991, até atingir $30 \%$ em 2000. Por fim, também para as mulheres, a principal mudança nos anos 1990 foi a emergência do desemprego como fenômeno importante, destino de cerca de $20 \%$ das jovens de 18 anos ou mais em 2000. A inatividade já não era o destino modal, competindo intensamente com a escola, o emprego e o desemprego. Entre empregadas e desempregadas, tínhamos $61 \%$ das mulheres na força de trabalho em 2000.

Ou seja, até 1991, a maioria das mulheres, diferentemente dos homens, não migravam da escola para o trabalho nem para a força de trabalho; migravam sobretudo para a inatividade. Esse destino migratório era a contrapartida feminina da migração em forma chiástica dos homens, que deixavam a escola para empregar-se de forma precária e insegura. As mudanças estruturais profundas dos anos 1990 mexeram bastante nesse quadro, com as mulheres permanecendo por mais tempo na escola; entre as que a haviam deixado, uma proporção maior passou a pressionar o mercado de trabalho, com isso reduzindo a taxa de inatividade em comparação com as décadas anteriores, mas aumentando proporcionalmente a taxa de desemprego, sobretudo entre aquelas com 17 e 18 anos. Nesse quadro, boa parte das mudanças na estrutura do mercado de trabalho nos anos 1990 deve ser creditada à entrada maciça das mulheres jovens como demandantes de emprego (cf. Gráfico 7). 


\section{Gráfico 7}

Transições a Partir da Escola - Mulheres, Brasil: 1970-2000
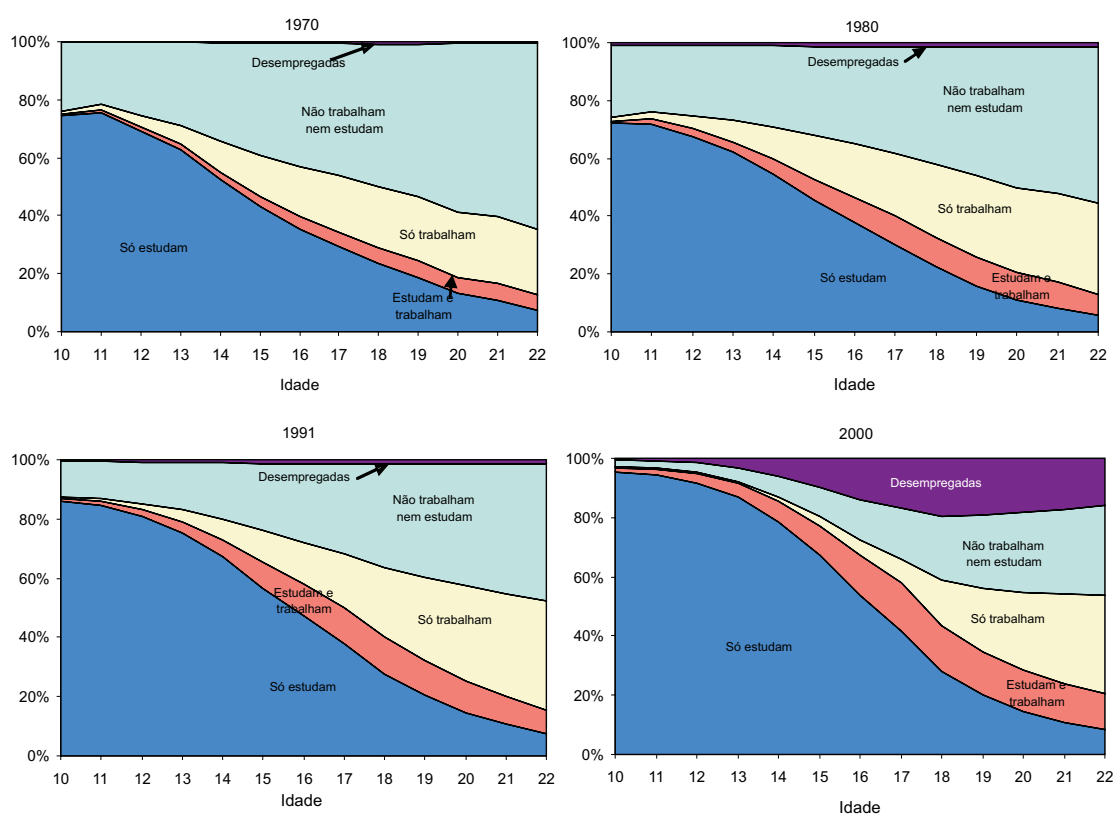

Fonte: IBGE, microdados do Censo Demográfico de 1980.

Esses dados permitem avançar no argumento em construção aqui. Em uma situação de pobreza ou de renda muito baixa, em que entre $70 \%$ e $75 \%$ da população empregada ganhava $\mathrm{R} \$ 900$ ou menos, a escola não era encarada como condição para a inserção no mercado de trabalho, ainda que os mais escolarizados conseguissem as melhores posições (como será visto). As ocupações, em sua maioria, não eram de qualidade, e qualificar-se não devia parecer racional a pessoas vivendo em famílias de renda per capita muito baixa e que careciam, por isso mesmo, do aporte de cada um para a composição do orçamento doméstico. A contrapartida eram as jovens, que permaneciam ainda menos na escola, porque seu destino não era o mercado de trabalho, mas sim a vida doméstica, seja como filhas, seja como esposas precoces ${ }^{45}$. Homens e mulheres deixavam a escola em momentos semelhantes do curso de vida para compor trajetórias pessoais que combinavam emprego precário dos homens com subordinação das mulheres ao trabalho doméstico em condições de pobreza ou de renda muito baixa.

Com isso, pode-se dizer que o desenvolvimentismo, que marcou a trajetória ascendente da economia brasileira entre 1950 e 1980, e a estag- 
nou pelos anos seguintes, até pelo menos o fim da década de 1990, produziu um padrão de percurso da escola para o trabalho, por parte dos jovens, altamente desestruturado, no sentido de que a educação formal não representou o principal mecanismo de qualificação para o trabalho. De um lado (da demanda), o mercado de trabalho urbano em constituição não oferecia, majoritariamente, posições que exigissem qualificação formal daqueles que nele aportavam ano a ano em busca de meios de vida. O emprego urbano típico no país era de baixa qualidade: mal remunerado, instável, em grande medida sem proteção da legislação trabalhista e exigindo pouca ou nenhuma qualificação formal; e isso igualmente para os jovens e os mais velhos ${ }^{46}$. A interrupção da trajetória ascendente de crescimento econômico nos anos 1980 perpetuou esse quadro para além do que se poderia esperar, sobretudo porque a melhoria gradual (embora lenta) da qualificação formal de homens e mulheres não foi recompensada com melhoria na renda total. A maioria da população ganhava, em 1991 (e também em 2000), aproximadamente o mesmo que em 1970. Urbanização foi sinônimo de mobilidade social, mas também de desigualdade e pobreza (Brant e Singer, 1976; Costa Ribeiro, 2007).

De outro lado (da oferta), boa parte das famílias não investia na qualificação de seus membros mais jovens, em parte porque o mercado de trabalho não recompensaria esses investimentos, e em parte porque a educação formal, dispendiosa e, competindo com o mercado de trabalho pelo tempo disponível dos filhos, demorou a ser valorizada em si mesma como aspecto central da cidadania. A origem rural das famílias, marca estrutural do país por quase todo o período, teve papel relevante aqui ${ }^{47}$. O trabalho no campo exigia níveis mínimos de escolaridade, o saber ocupacional sendo transferido de forma prática de uma geração a outra pelos progenitores, os membros mais velhos das famílias, os capatazes das fazendas etc. A escola como formadora para o trabalho era desnecessária ou acessória.

Esse quadro geral não dá conta de todo o movimento de mudança, obviamente. O Brasil é (e sempre foi) profundamente desigual. Qualquer construção de padrões típicos deixa nas sombras parcelas significativas da população. Por isso, o desenho deve ser matizado. Ainda que, já no ano 2000, uma proporção significativa dos trabalhadores urbanos trouxesse a marca da herança rural, própria ou de seus pais, uma parte era oriunda das próprias cidades e possuía trajetórias urbanas desde muitas gerações. Essas pessoas ocuparam as melhores posições e com- 
puseram a elite superior do mercado de trabalho, transferindo a seus filhos, via herança e/ou investimento em educação formal, os capitais simbólico, social e econômico acumulados. Para que se tenha uma idéia da capacidade de esses segmentos transferirem aos filhos seus capitais, em 1982, 77\% dos pais com ensino superior tinham filhos cursando ou concluindo a faculdade. Entre os pais com colegial completo, essa proporção era de $67 \%$. Na outra ponta, apenas $26 \%$ dos pais com primário completo tinham conseguido levar os filhos à faculdade ${ }^{48}$. Para os dois primeiros estratos (de pais mais escolarizados), a transição da escola para o trabalho tinha sentido diverso do que para a maioria da população: a ocupação era uma decorrência mais ou menos natural do investimento das famílias na qualificação de seus membros. Todo um conjunto de profissões, algumas mais outras menos reguladas pelo Estado, compunha esse estrato ocupacional acessível apenas a uma parcela diminuta da população, em parte porque era pequena a oferta de educação superior, em parte porque era pequeno o número de famílias que podiam investir nessa direção.

Outra parte dos migrantes ou filhos de migrantes também teve sucesso no mercado de trabalho, embora em menor medida e não necessariamente decorrente da educação formal. As histórias de sucesso individual pelo auto-empreendimento podem não ter sido majoritárias, mas não foram negligenciáveis. Apenas, para essas pessoas, falar em transição da escola para o trabalho nem sempre fazia sentido. Foi sempre muito alta a proporção de empregadores com nenhuma ou quase nenhuma escolaridade formal; e uma parcela não-desprezível dos filhos de migrantes ascendeu pela escolarização ( $26 \%$ dos pais com primário completo com filhos na faculdade em 1982, por exemplo).

Pode-se tornar ainda mais complexa essa caracterização, com matizes no interior desses grandes grupos, incluindo, por exemplo, distinções regionais e mesmo no interior para cada região do país, além de distinções raciais. No entanto, o dito é suficiente para embasar o que denominei aqui padrão desenvolvimentista de transição da escola para o trabalho, caracterizado, além do que se disse nos parágrafos anteriores, por profunda desigualdade nas oportunidades de acesso à escola e, configurado o acesso a esta, nas oportunidades de transição para o trabalho. Desigualdade, ademais, transferida de uma geração a outra até muito recentemente, em um processo que apresentou grande inércia estrutural. Esse padrão foi rompido nos anos 1990, em razão das profundas mudanças estruturais por que passou a economia brasileira 
que, entre outros fatores, fizeram crescer o desemprego, aumentando a competição dos jovens pelas ocupações existentes e dificultando sua primeira inserção profissional.

\section{O Rompimento do Padrão Desenvolvimentista de Inserção Ocupacional}

É preciso insistir que as mudanças recentes na estrutura econômica afetaram as chances de entrada no mercado dos jovens, mas não pioraram a sempre precária configuração do mercado de trabalho brasileiro, característica marcante do desenvolvimentismo. A perda de qualidade das ocupações nos anos 1990, detectada por Sabóia (1999), ocorreu sobretudo nas regiões metropolitanas. Quando olhamos o Brasil, o quadro, uma vez mais, é de grande inércia estrutural. Um dos principais indicadores disso, como já mencionado, foi a relativa estagnação da renda entre 1970 e 2000. Dois outros, igualmente relevantes, merecem destaque: o tempo de emprego das pessoas e a taxa de informalidade das ocupações.

Começando por essa última, a Tabela 6 não deixa dúvidas sobre a estabilidade, em trinta anos, dos tipos de emprego disponíveis no mercado de trabalho nacional ${ }^{49}$. Entre 1976 e 2005, vemos apenas um ligeiro aumento dos assalariados (com e sem carteira) e um aumento maior dos empregadores, ambos tendo roubado posições dos trabalhadores por conta própria e dos não remunerados. Os empregadores, contudo, saíram de uma posição muito baixa, e seu crescimento constante e substancial no período os trouxe a uma participação ainda assim pequena

Tabela 6

Evolução da Posição na Ocupação - Brasil

(1976-2005)

\begin{tabular}{|c|c|c|c|c|c|c|}
\hline Posição na Ocupação & 1976 & 1986 & 1996 & 1999 & 2005 & $\begin{array}{c}\text { Dissimilaridade } \\
2005 / 1976^{50}\end{array}$ \\
\hline $\begin{array}{l}\text { Empregado com carteira } \\
\text { e servidor público }\end{array}$ & 39,3 & 38,2 & 39,0 & 37,6 & 41,3 & 5,20 \\
\hline Empregado sem carteira & 21,4 & 27,9 & 24,2 & 24,0 & 24,4 & 14,25 \\
\hline Conta própria & 24,5 & 22,9 & 23,4 & 24,3 & 22,7 & 7,49 \\
\hline Empregador & 2,5 & 3,4 & 3,9 & 4,3 & 4,4 & 76,29 \\
\hline Não remunerado & 12,2 & 7,6 & 9,5 & 9,7 & 7,1 & 41,51 \\
\hline
\end{tabular}

Fonte: IBGE, microdados da PNAD. 
no emprego total (4,4\% em 2005). Na verdade, o quadro geral é de pequena deterioração, nos anos 1990, das posições existentes em 1986, com aumento do trabalho por conta própria e não remunerado e redução do assalariamento com carteira. A deterioração, segundo esse primeiro indicador, fora contida em 2005, mas a maioria das posições ocupacionais permanecia muito precária: $55 \%$ delas eram por conta própria, assalariadas sem carteira ou não remuneradas, praticamente a mesma proporção de trinta anos antes.

O segundo elemento de relevo é o tempo de emprego na ocupação atual. Não tomo essa medida como indicador de boa qualidade da ocupação. Primeiro, porque é possível argumentar que, no mundo contemporâneo, a permanência no mesmo emprego já não é um valor, pois típico da relação salarial fordista ${ }^{51}$. No pós-fordismo, ou no mundo da acumulação flexível (Harvey, 1992), em que impera a ideologia do trabalhador como "empresário de si mesmo" (Boltanski e Chiapello, 2002), a idéia do emprego para a vida toda, ou como um bem, cativo do trabalhador, já não faria sentido. Em segundo lugar, em mercados de trabalho estruturalmente precários, como foi visto aqui, a permanência no emprego, para a maioria das pessoas, pode significar a manutenção de condições precárias de trabalho e de vida. Longas permanências significariam, portanto, fechamento do mercado à possibilidade de mobilidade social.

Por outro lado, supondo-se, de forma bastante realista, que os trabalhadores preferem estar ocupados a desempregados, em um ambiente em que o seguro-desemprego exclui quem não tem emprego formal e, além disso, tem duração menor do que o tempo de desemprego de boa parte das pessoas ${ }^{52}$; e supondo-se que a probabilidade de permanecer ocupado é maior do que a de conseguir uma ocupação, situação que é diretamente proporcional à taxa de desemprego global; então (isto é, se o desemprego é alto o bastante para pôr em risco as chances de uma recolocação), os trabalhadores preferirão permanecer na ocupação em que estão. Dá-se o mesmo no caso de o mercado de trabalho oferecer poucas oportunidades de melhoria de posição para uma proporção muito grande de trabalhadores com a mesma qualificação. Ou seja, em mercados de trabalho muito competitivos, seja por causa do desemprego, seja em razão de excedentes de população com qualificação semelhante, os trabalhadores tenderão a valorizar a permanência no emprego atual. Logo, dependendo de que ponto se observe o mundo do trabalho, o tempo de emprego pode indicar tanto boa quanto má 
qualidade das ocupações. É por isso que ele será tratado aqui como aspecto da estrutura mesma do mercado de trabalho, que oferece tais ou quais perspectivas de carreira para as pessoas.

Tal como o anterior, esse indicador também apresenta inércia considerável, embora não existam dados sobre isso nas PNADs anteriores a $1992^{53}$. Como pode ser visto na Tabela 7, em média, entre 1992 e 2005, cerca de $54 \%$ das pessoas de 25 anos ou mais ocupadas estavam no mesmo emprego havia cinco anos ou mais ${ }^{54}$. Analisando essa questão, fica claro que houve leve deterioração das posições mais precárias, em razão do aumento de pouco mais de $7 \%$ no tempo de permanência nos empregos por conta própria, sem carteira e não remunerados (supondo-se, obviamente, que esses ocupados prefeririam estar em uma ocupação registrada, a permanência expressando má qualidade do emprego). Isto é, as posições mais mal situadas no mercado tornaram-se um pouco mais estáveis para seus ocupantes, mas a uma taxa que não permite que se fale em tendência geral de aumento da precariedade no mercado de trabalho.

Considerados esses três indicadores de qualidade de emprego (renda, taxa de formalidade e tempo de emprego dos ocupados), tudo indica que as mudanças no mercado de trabalho, com deslocamento do emprego industrial em favor dos serviços urbanos, não afetou diretamente, em âmbito nacional, a estrutural precariedade das ocupações, que, desse ponto de vista, marca o desenvolvimentismo desde sempre. O que mudou foi a quantidade de empregos disponíveis nacionalmente, a qual, crescendo a

Tabela 7

Proporção de Ocupados de 25 Anos de Idade ou Mais que Estavam no Emprego Havia Cinco Anos ou Mais

\begin{tabular}{l|c|c|c|c|c|c}
\hline Posição na Ocupação & $\mathbf{1 9 9 2}$ & $\mathbf{1 9 9 6}$ & $\mathbf{1 9 9 9}$ & $\mathbf{2 0 0 1}$ & $\mathbf{2 0 0 5}$ & $\begin{array}{c}\text { Dissimilaridade } \\
\mathbf{2 0 0 5 / 1 9 9 2}\end{array}$ \\
\hline $\begin{array}{l}\text { Empregado com carteira e } \\
\text { servidor público }\end{array}$ & $52,3 \%$ & $52,9 \%$ & $53,6 \%$ & $51,9 \%$ & $51,5 \%$ & 1,53 \\
Empregado sem carteira & $32,0 \%$ & $33,2 \%$ & $33,5 \%$ & $33,4 \%$ & $34,4 \%$ & 7,50 \\
Conta própria & $62,4 \%$ & $65,8 \%$ & $65,4 \%$ & $64,6 \%$ & $66,8 \%$ & 7,05 \\
Empregador & $70,2 \%$ & $68,3 \%$ & $71,0 \%$ & $69,8 \%$ & $73,6 \%$ & 4,84 \\
Não remunerado & $69,0 \%$ & $70,7 \%$ & $71,6 \%$ & $71,8 \%$ & $74,2 \%$ & 7,54 \\
Média & $53,4 \%$ & $54,6 \%$ & $55,0 \%$ & $53,5 \%$ & $54,2 \%$ & 1,50 \\
\hline
\end{tabular}

Fonte: IBGE, microdados da PNAD. 
taxas menores do que o crescimento da PEA, resultou em aumento do desemprego global e dos jovens em particular.

Com isso, posso provisionalmente definir o rompimento do padrão desenvolvimentista de transição da escola para o trabalho como tendo se caracterizado por três vetores principais: 1) o adiamento da entrada dos jovens no mercado de trabalho;2) o desemprego no início das trajetórias de vida;3) o conseqüente aumento da competição pelas posições de mercado. Ou seja, a escola adquiriu cada vez maior centralidade nas chances de inserção dos jovens, mas essas chances se tornaram muito mais restritas e de acesso mais lento, em comparação com os jovens de gerações anteriores ${ }^{55}$.

\section{Entre a escola e o trabalho - inserção de classe}

Isso não é tudo. Se o acesso ao mercado de trabalho piorou em razão do desemprego, em um ambiente de relativa permanência da má qualidade estrutural das ocupações, é preciso avaliar qual é o impacto disso sobre as oportunidades de inserção dos jovens na estrutura social. $\mathrm{O}$ aumento do desemprego e da competição pelas posições influiu nas chances de classificação social dos jovens? Seja qual for a resposta, há diferenças segundo o sexo e a escolaridade? Em outras palavras, que preço as mudanças recentes cobraram dos jovens em termos de oportunidades de vida? Para responder a essas perguntas, analiso, em seguida, as trajetórias de jovens nascidos em 1970, 1975 e 1980 que haviam deixado a escola, acompanhando-os dos 18 aos 25 anos de idade, segundo sua situação de classe. Distingo, nesse último caso, as trajetórias de pessoas que abandonaram cedo os estudos (com oito anos de escolaridade ou menos) e as que completaram onze anos ou mais, segundo a classe social de destino. Utilizo, nesta análise, os dados da PNAD de 1981 a 2005, a partir dos quais construí coortes fictícias (ou hipotéticas) de nascidos naqueles anos de referência ${ }^{56}$.

O Gráfico 8 apresenta as transições de homens jovens que tinham até oito anos de escolaridade (seqüência de gráficos na coluna da direita) e mais de onze anos (seqüência na coluna da esquerda), e que, ademais, já haviam deixado a escola. Os gráficos são apresentados segundo a classe social de destino dos nascidos naqueles anos de referência com idades entre 18 e 25 anos $^{57}$.

Comparando-se os homens com mais estudo e aqueles com menos estudo, a primeira característica que salta aos olhos é a enorme diferença 


\section{Gráfico 8}

Transições de Jovens Homens com até Oito e com Onze Anos de Escolaridade ou Mais, Nascidos em 1970, 1975 e 1980 e que Tinham Deixado a Escola - Brasil
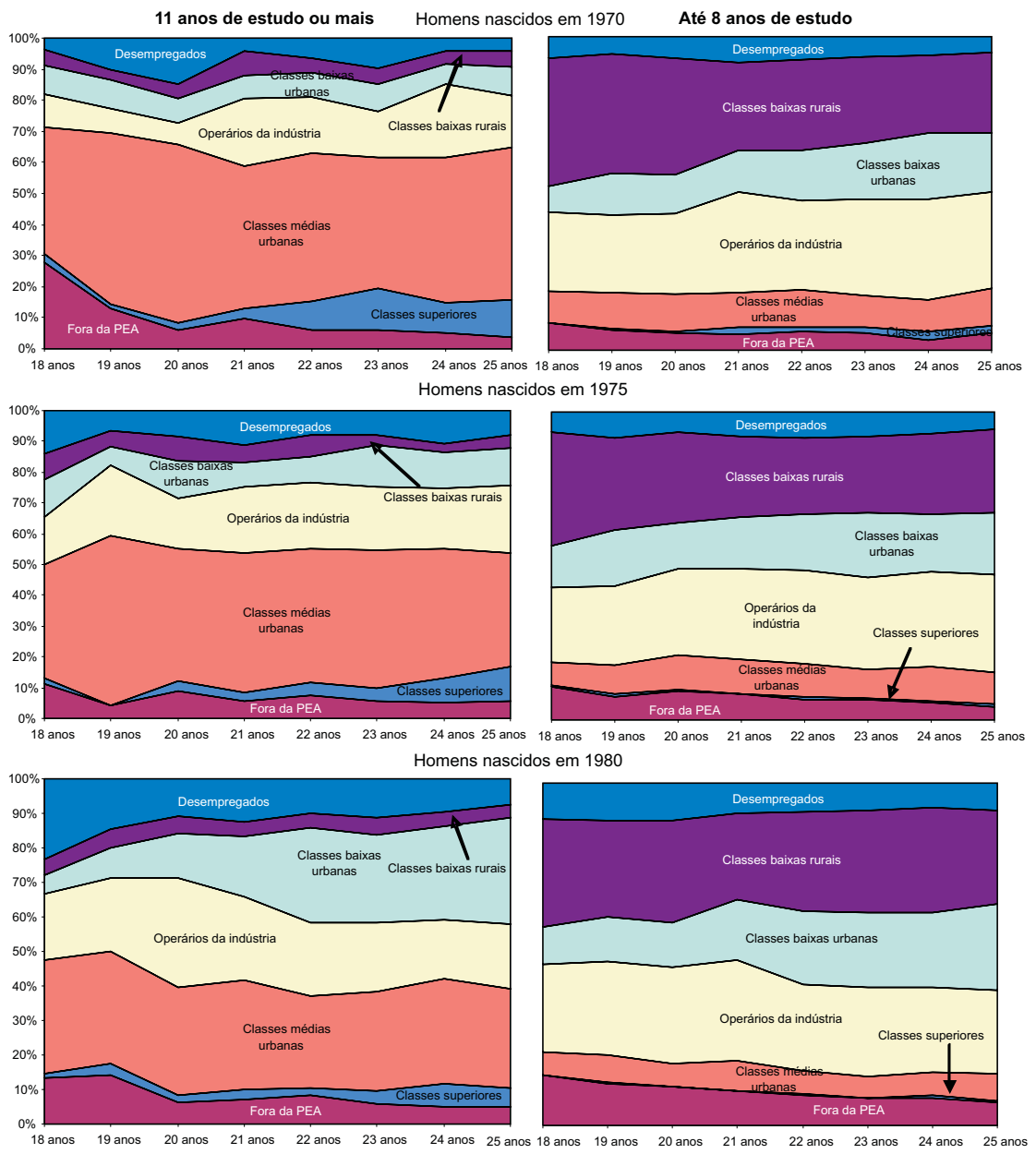

Fonte: IBGE, microdados da PNAD (1981-2005).

de destinos de classe segundo a educação. Ao deixar a escola, os mais escolarizados vão compor, majoritariamente, as classes médias e, em menor proporção, as classes superiores urbanas, enquanto os menos escolarizados vão constituir as classes baixas, rurais ou urbanas, aqui incluído o serviço doméstico. Proporção não-desprezível dos menos escolarizados destina-se ao trabalho industrial, caminho trilhado por estrato bem menor dos mais escolarizados. Desse ponto de vista, a es- 
colaridade se apresenta, como já demonstrou a literatura pertinente ${ }^{58}$, como importante fator condicionante dos destinos de classe.

O segundo aspecto saliente é o fato de as probabilidades de percurso de ambos os grupos educacionais mudarem para os nascidos a cada cinco anos - a mudança é intensa para os mais escolarizados e muito lenta para seus congêneres de menor educação formal. No caso dos primeiros, há um aumento gradativo das probabilidades de percurso em direção às classes baixas (incluindo-se o operariado industrial) e, em contrapartida, redução das chances de acesso às posições superiores na estrutura social. No caso dos nascidos em 1980, é visível a dificuldade de os recém-chegados ao mercado de trabalho atingirem as mesmas posições superiores de seus congêneres de 1975 ou de 1970. Aos 20 anos de idade, por exemplo, apenas um terço dos primeiros estava nas classes médias urbanas ou superiores. Entre os nascidos em 1970, eles eram 60\%; para a coorte de 1975, 46\%. Do mesmo modo, dos nascidos em 1970, a proporção que compôs as classes superiores e médias urbanas, que era de $43 \%$ quando os jovens tinham 18 anos, subiu para $61 \%$, considerando a idade de 25 anos. Apenas $14 \%$ estavam nas classes baixas urbanas e rurais. Entre os nascidos em 1980, o quadro mudara de maneira substancial. De um lado, porque a participação das classes superiores e médias urbanas na probabilidade dos jovens não mudou ao longo da vida, permanecendo em $34 \%$ até os 25; portanto, bem abaixo das chances dos nascidos dez anos antes. De outro lado, a presença de pessoas mais escolarizadas nas classes baixas urbanas deu um salto substancial, de $14 \%$ para a idade de 25 anos, considerando os nascidos em 1970, para 31\% dos nascidos em 1980.

Analisando mais detalhadamente essa coorte em particular (homens nascidos em 1980), fica evidente a maior dificuldade em encontrar seu primeiro emprego. Aos 18 anos (portanto, em 1998, quando a taxa de desemprego, segundo a mesma PNAD, era de 9\%), 23\% dos homens estavam desempregados. À medida que o tempo passava e esses jovens iam se engajando no mercado de trabalho, seu destino mais provável eram o operariado industrial e as classes baixas urbanas. De tal modo que, aos 25 anos de idade, nada menos do que $54 \%$ dos jovens mais escolarizados estavam nas classes baixas (inclusive rurais, emprego doméstico e operariado industrial). Dos nascidos em 1970, esses destinos congregavam, no final do período, apenas $31 \%$ daqueles com escolaridade igual ou maior do que onze anos de estudo (38\% para os nascidos em 1975). Houve, portanto, uma deterioração das condições 
de acesso às melhores posições de classe por parte dos mais escolarizados.

É preciso destacar que esses percursos de classe estão fortemente condicionados por aqueles que, tendo completado o colegial, nunca chegaram a cursar o ensino superior. Se desconsiderarmos esses últimos, o quadro muda bastante. Dos graduados nascidos em 1980, por exemplo, $80 \%$ estavam nas classes superiores ou médias urbanas aos 25 anos. Dos nascidos em 1970, essa proporção era de $78 \%{ }^{59}$. Logo, o que parece estar ocorrendo é o fechamento gradativo das posições superiores da hierarquia social aos não-portadores de diploma universitário, combinado com o aumento da proporção de titulados na população to$\operatorname{tal}^{60}$, que parece estar aumentando a competição por aquelas posições.

Um terceiro aspecto que chama a atenção é a persistência relativa da participação dos jovens com até oito anos de estudo que eram membros das classes baixas rurais. É verdade que, no caso da coorte de 1970, ocorre queda acentuada nessa participação à medida que os jovens envelhecem, ao passo que aumenta a proporção de membros das classes baixas urbanas e do operariado industrial. Trata-se, como parece claro, do resultado mais evidente do processo permanente de urbanização que, trazendo do campo jovens reiteradamente pouco escolarizados, os destinou às classes menos favorecidas. Como já mencionado, os migrantes do campo melhoraram sua posição de classe ao chegar às cidades, mas se alocaram em posições inferiores na hierarquia ocupacional urbana. Esse movimento foi bem menos intenso para os nascidos em 1975, e praticamente deixou de ocorrer para os nascidos em 1980. Nesse caso, os menos escolarizados do campo permaneceram ali à medida que envelheceram. Discuto mais longamente esse movimento na conclusão.

O quarto ponto a se salientar no caso dos jovens do sexo masculino é que as posições superiores na hierarquia social foram sendo gradativamente fechadas aos menos escolarizados. Entre os nascidos em 1970 e $1975,14 \%$ e $11 \%$, respectivamente, compunham as classes médias urbanas e as classes superiores. Já para a coorte de 1980, essas posições eram o destino de apenas $8 \%$ deles.

Por fim, cabe marcar que as probabilidades de classe encontradas aos 25 anos, sobretudo para os menos escolarizados, eram um preditor bastante adequado de suas probabilidades futuras. No caso dos nascidos em 1975, por exemplo, que puderam ser rastreados na PNAD até a 
idade de 30 anos (em 2005), a diferença entre as probabilidades de classe nessa idade e as encontradas quando tinham 25 anos era de apenas $7 \%$ para aqueles com até oito anos de escolaridade ${ }^{61}$. Para os nascidos em 1970, a diferença era de $9 \%$ (comparando as probabilidades aos $25 \mathrm{e}$ aos 30 anos). No caso dos mais escolarizados, os valores eram bem mais altos, de $25 \%$ e $21 \%$, respectivamente. Ou seja, as probabilidades de destino dos jovens de ambos os estratos eram bastante claras aos 25 anos de idade, mas as dos menos escolarizados eram mais fechadas do que as de seus congêneres com mais anos de estudo. Isso quer dizer que as oportunidades de mobilidade social no curso de vida eram também menores para os primeiros, com exceção, obviamente, daqueles que ainda viviam (ou trabalhavam) no campo.

A grande proporção de homens desempregados ou fora da PEA na coorte de 1980 sugere que a estrutura de classe descrita até aqui ainda estaria em movimento, sobretudo no caso dos mais escolarizados. Isto é, os nascidos em 1980 permaneceram mais tempo na escola, ingressando mais tarde no mercado de trabalho e vivendo períodos por vezes longos de desemprego entre ocupações, o que tornaria suas trajetórias menos previsíveis no médio prazo. Uma maneira de mensurar essa possível imprevisibilidade é avaliar quão próxima a estrutura de classe desses jovens está da estrutura de classe global dos homens com mais escolaridade. Isso porque essa última pode ser tomada como a estrutura de probabilidades de destino de qualquer pessoa, jovem ou não, ou, o que dá no mesmo, como o conjunto de posições existentes no mercado de trabalho em um momento dado do tempo (no caso, 2005). Se a estrutura de classe dos jovens e da PEA total for muito distinta, devemos esperar a continuidade da mobilidade social e a eventual mudança na estrutura de classe da coorte de 1980. Do contrário, estaremos diante, já aos 25 anos, do máximo que essas pessoas conseguiriam mesmo se tivessem nascido mais cedo.

No caso dos homens, então, a disparidade média entre as posições de classe da PEA mais escolarizada e as dos jovens na mesma condição era de $27 \%$, se desconsiderarmos os que estavam fora da PEA em ambas as distribuições ${ }^{62}$. Os jovens estavam sobre-representados principalmente nas classes baixas urbanas (32\% contra $22 \%$ da PEA com onze anos de escolaridade ou mais) e sub-representados nas classes superiores ( $6 \%$ contra $12 \%$ na PEA). Considerando-se os jovens com até oito anos de estudo, a diferença entre sua estrutura de classe e a de todos os ocupados com a mesma escolaridade era de apenas $12 \%$. É importante 
marcar que, no caso dos mais escolarizados, a disparidade era puxada pela sobre-representação dos jovens nas classes baixas urbanas e no serviço doméstico e pela sub-representação nas classes superiores. Entre os menos escolarizados, o desemprego juvenil e a menor participação nas classes médias e superiores urbanas eram responsáveis pela maior dissimilaridade de destino.

Isso quer dizer, em suma, que provavelmente os jovens mais escolarizados de 25 anos em 2005 conseguissem melhorar um pouco sua posição de classe nos anos seguintes, uma parte deles deixando as classes baixas em direção às classes médias e superiores. Isso teria como efeito mudar aproximadamente 30\% (no caso dos homens mais escolarizados) a estrutura de posições encontrada quando eles tinham $25 \operatorname{anos}^{63}$. Para os demais jovens, a mudança média não ultrapassaria os $20 \%$, e a saída do desemprego responderia por boa parte da mudança total em todos os casos.

Desse modo, a melhoria nas condições de escolarização da população jovem em idade ativa, desvendada pela análise dos dados dos censos demográficos entre 1970 e 2000, parece ter resultado em pelo menos dois processos correlatos. Em primeiro lugar, o aumento da concorrência no topo da hierarquia de posições sociais, fruto tanto do crescimento do número de diplomados quanto do crescimento lento das posições superiores, restringiu, ano a ano, as chances de acesso dos homens menos escolarizados. As classes superiores passaram a ser destino quase exclusivo dos portadores de diploma universitário. Em segundo lugar, a reestruturação econômica dos anos 1990 restringiu as possibilidades em geral de acesso dos jovens ao emprego - restrição maior para os mais escolarizados. É provável que, diante da deterioração das condições do mercado de trabalho, com o aumento impressionante da participação relativa das posições inferiores, os mais escolarizados tenham recusado empregos incompatíveis com sua qualificação. Isso pressionou as taxas de desemprego até determinado momento de sua trajetória de vida (em torno dos 20 anos), quando então trocaram o desemprego por ocupações na base da pirâmide social, isto é, as classes baixas urbanas, aqui incluído o emprego doméstico, antes destino de baixíssima probabilidade para aqueles com onze anos de estudo ou mais.

No âmbito das mudanças de mais largo curso, no caso dos jovens com oito anos de estudo ou menos, a expansão escolar nas cidades ao longo 
dos anos 1990 parece explicar parte do aparente paradoxo da perda de participação da agricultura no emprego total e seu aumento entre os menos escolarizados, quando comparamos os homens nascidos em 1980 e nos qüinqüênios anteriores. Isto é, há mais jovens de menor escolaridade nas classes baixas rurais entre os nascidos em 1980 não porque tenha aumentado a proporção de trabalhadores rurais na população, mas porque havia menos pessoas com oito anos ou menos de estudo nas cidades, o que fez aumentar a proporção relativa de trabalhadores rurais na distribuição. Não se trata, portanto, da interrupção do processo de saída do campo para radicar-se nas posições inferiores da hierarquia social urbana, embora tenha havido importante redução do ritmo do êxodo rural: em 1999, 23\% da PEA era agrícola, contra 20,3\% em 2005, conforme a mesma PNAD. Finalmente, para os homens menos escolarizados, o desemprego não representou o mesmo flagelo que no caso de seus congêneres de maior escolaridade, talvez porque lhes fosse mais difícil adiar a entrada no mercado de trabalho, o que os estaria encaminhando para as classes sociais mais baixas.

\section{CONCLUSÃO}

O padrão desenvolvimentista de transição da escola para o trabalho que se tentou reconstituir aqui recobre curto período histórico, no qual transformações profundas ocorreram em ritmo acelerado, mudando constantemente os parâmetros estruturais que orientaram as decisões de indivíduos e famílias sobre suas vidas e carreiras. Contudo, não obstante o ritmo e a profundidade das mudanças, as escolhas das gerações de brasileiros nascidos entre 1948 e 1990 resultaram, no agregado, em dinâmicas sociais dotadas de apreciável inércia. $\mathrm{O}$ conjunto populacional urbano estava sempre recebendo novas (e grandes) levas de migrantes, com isso repondo constantemente a "herança do passado" representada pela baixa (ou nula) escolaridade dos trabalhadores do campo. Esses migrantes, conquanto vendo melhorar sua posição de classe pelo simples fato de deixarem para trás a pobreza rural, encontraram mercados precários de trabalho nas cidades, com padrões de regulação pública, qualidade de emprego e remuneração muito aquém do que seria de se esperar de uma sociedade que viu seu PIB ser multiplicado por quinze em quarenta anos. O desenvolvimentismo produziu empregos precários, desprotegidos, inseguros e mal remunerados, algo que se aprofundou com sua débâcle ainda nos anos 1980. 
Esse quadro geral esconde importantes nuances, obviamente, já que o Brasil é estruturalmente desigual, em múltiplas dimensões. Oferta e demanda de força de trabalho pouco qualificada convergiram em uma infinidade de setores econômicos, como a construção civil, a indústria tradicional, o comércio varejista e os serviços pessoais, de reparação e outros, que ocuparam, historicamente, o maior contingente populacional urbano. No Brasil, os baixíssimos níveis de escolaridade da grande maioria dos trabalhadores encontraram condições de demanda compatíveis, e a baixa escolaridade não configurou obstáculo à inserção ocupacional. Isto é, para a maioria dos brasileiros, a escola não se mostrou importante para as chances de emprego nos anos 1960 e 1970, e também na década de 1980, tanto no campo quanto na cidade. A escolaridade, nesse sentido, não hierarquizou as chances de inserção social senão de uma fatia minoritária dos trabalhadores, aqueles que, já nas cidades há uma ou duas gerações, não abandonaram a escola na adolescência.

Se a escola não foi determinante para o destino ocupacional da maioria dos brasileiros durante o desenvolvimentismo, por outro lado, ela encaminhava os jovens mais escolarizados para as posições superiores da estrutura social. As posições médias e superiores apresentavam barreiras à entrada, exigindo escolaridade quase sempre inacessível para os trabalhadores pobres urbanos e seus filhos ${ }^{64}$. Isso contribuiu para que os padrões de escolarização dos jovens mudassem muito lentamente, em comparação com seus pais, mesmo sendo a educação genericamente valorizada como aspecto essencial do desenvolvimento (Gouveia, 1989).

A expansão do sistema educacional nos anos 1980 e, sobretudo, $1990^{65}$, combinada, nessa última década, com reestruturação econômica e produtiva desindustrializante, mudou bastante esse quadro. Assistiu-se ao aumento das exigências de escolaridade para as posições superiores, com a conseqüente deterioração das probabilidades de classe dos mais escolarizados em comparação tanto com as coortes mais antigas de nascimento quanto com os próprios pais. Isto é, um homem de 25 anos com onze anos ou mais de escolaridade em 1970 estaria, com grande probabilidade, nas classes médias ou superiores urbanas. Seu filho de 25 anos, em 2000, com a mesma escolaridade, tinha chances não-desprezíveis de figurar entre as classes baixas e mesmo entre o operariado industrial. Uma proporção importante estaria desempregada. 
Dizendo de outro modo: no desenvolvimentismo, a escolarização era elemento importante dos projetos de carreira de indivíduos e famílias, conquanto inacessível para os mais pobres (maioria da população) e para os migrantes do campo. $\mathrm{O}$ acesso desigual às posições superiores do sistema educacional garantia aos que o logravam, indivíduos e famílias, as melhores posições na estrutura de classe. Isso começou a mudar já no início dos anos 1980, como bem identificou Reginaldo Prandi em livro pioneiro (1982) que mensurou a perda de valor das credenciais educacionais conseguidas no ensino superior. Transitar da escola para as melhores posições no mercado de trabalho deixou de ser uma operação automática para esses indivíduos, e esse processo se aprofundou nos anos 1990 e 2000.

Isso não se deveu, é importante salientar, a uma piora das posições existentes no mercado de trabalho com o fim do desenvolvimentismo. O que houve foi um grande aumento do desemprego juvenil, em especial entre os mais escolarizados, além do crescimento da taxa de participação das mulheres. Ambos aumentaram sobremaneira a competição pelas posições superiores, que por sua vez não cresceram na mesma proporção do crescimento das credenciais educacionais das pessoas, com isso levando a que estas, mesmo muito escolarizadas, passassem a ocupar posições inferiores às que ocupariam se tivessem nascido dez ou vinte anos antes.

A deterioração das condições de classe foi grande também para os menos escolarizados. É verdade que eles continuaram lutando pela sobrevivência nas ocupações precárias de sempre, mas a diminuição das chances de emprego industrial encaminhou mais trabalhadores para as classes baixas urbanas (em que impera a informalidade), para o desemprego e a inatividade. Chegou a $14 \%$ a proporção de jovens homens nascidos em 1980 que estavam sem emprego e fora da escola aos 18 anos de idade. Somando-se os desempregados, tínhamos um quarto dos jovens menos escolarizados sem trabalho aos 18 anos. Aos 25 anos, essa proporção era ainda muito alta, $15 \%$. Ou seja, as probabilidades de inserção de classe dos nascidos em 1980, ainda que não muito distantes daquelas dos nascidos em 1970 em comparação com os mais escolarizados, eram piores em razão tanto do aumento do desemprego quanto do crescimento da inatividade.

O aumento global da escolaridade da população, pois, teve como efeito, paradoxalmente, piorar as condições de entrada no mercado de tra- 
balho dos jovens de todos os perfis educacionais. Tal situação só pode ser explicada pelo ritmo mais lento de crescimento dos postos de trabalho em comparação com o crescimento da PEA, o que aumentou a competição pelas posições existentes em todos os segmentos ${ }^{66}$. Isso configura um quadro de duradoura reversão das expectativas de mobilidade social dos mais jovens, mais ou menos escolarizados igualmente, cujos efeitos para a dinâmica social ainda estão por ser adequadamente desvendados.

(Recebido para publicação em novembro de 2007)

(Versão definitiva em maio de 2008)

\section{NOTAS}

1. Para detalhes sobre o PNPE, visite www.mte.gov.br, onde se pode ler que "o objetivo do PNPE é contribuir para a geração de oportunidades de trabalho decente para a juventude brasileira [...]".

2. Para balanço bastante preliminar do PNPE, ver Andrade (2005).

3. Argentina, Chile, México e outros países emergentes adotaram políticas semelhantes. Para o caso de países da Organisation for Economic Co-Operation and Development - OECD, ver Müller e Gangl (2003) e Roulleau-Berger e Gauthier (2001).

4. Sobre essas diferentes temporalidades na configuração das chances de emprego, ver Granovetter (1974).

5. Um dos estudos recentes mais importantes sobre essa transição, no Brasil, é o de Hasenbalg (2003). Os efeitos da expansão escolar sobre a estratificação educacional no Brasil estão em Silva (2003). Camarano et alii (2001; 2003; 2004) e Corseuil, Santos e Foguel (2001) apresentam uma perspectiva econômica sobre a transição para a vida adulta. O desemprego juvenil, uma das faces da transição para o trabalho, também é objeto de análise minuciosa. Texto importante, de uma perspectiva sociológica, é o de Guimarães (2007). Ver também Tartuce (2007). Sobre a perda de valor das credenciais educacionais em anos recentes, no Brasil e no México, ver Torche e Costa Ribeiro (2007).

6. A literatura sobre o tema é vasta e não cabe enumerá-la aqui. Uma excelente análise do período de hegemonia do desenvolvimentismo no pensamento econômico brasileiro pode ser encontrada em Bielschowsky (1996). Furtado (1961) é referência obrigatória.

7. Exceto quando indicado, os dados utilizados nesta seção foram coligidos do CDROM anexo a IBGE (2003). Nas tabelas, cito a origem tal como aparece no CD-ROM. 
Singer (1981) e Faria (1983) são exemplos de estudos pioneiros na mesma direção do que apresento aqui. Santos (2006) e Costa Ribeiro (2007) retomam o tema.

8. Não foi possível obter dados relacionados ao período completo (1940-1980) para todos os países. Na Europa ocidental, o crescimento médio do PIB entre 1950 e 1973 foi de 2,94 vezes, com destaque para a Espanha, que teve seu PIB de 1950 multiplicado por 4,55 até 1973. Na América Latina, o México cresceu 4,15 vezes nesses 23 anos. O Brasil cresceu 5,27 vezes. Apenas o Japão superou essa taxa, multiplicando seu PIB de 1950 por 7,72 em 23 anos. Dados em OECD (2007).

9. O índice de Gini, uma das medidas mais populares de concentração de renda, saiu de 0,584 em 1981 para 0,636 em 1989 (Fonte: Ipeadata). A literatura sobre a crise dos anos 1980 é abundante no Brasil e na América Latina. Uma boa introdução são Bresser-Pereira (1996) e Cano (2000). Textos importantes e no calor da hora são de Bier et alii (1988), Singer (1988) e Appy (1993).

10. Para chegar a esse valor, basta multiplicar os índices da Tabela 2 pelo PIB da Tabela 1. Análise ampla das mudanças estruturais dos anos 1990 que levaram a esse resultado pode ser encontrada em Cardoso (2003). Ver também Kupfer, Ferraz e Iootty (2003). Sobre a desconcentração industrial entre 1970 e fins dos anos 1990, ver Pacheco (1999).

11. A primeira análise completa desse processo pode ser encontrada em Faria (1983). Ver também Faria (1991).

12. De fato, em 1960, os $10 \%$ mais ricos se apropriavam de $39,6 \%$ da renda; os $40 \%$ mais pobres, de 11,3\%. Em 1980, esses valores eram $51 \%$ e 8,8\%, respectivamente. Ver IBGE (1990).

13. Essas idéias foram defendidas pela primeira vez em Furtado (1966) e retomadas e aprofundadas, entre outros textos, em Furtado (1974). Oliveira (1972) é uma crítica contundente.

14. Não se trata, como apontou Faria (1991:104), de um processo de overurbanization, mas de um duplo movimento: concentração de população e emprego industrial nas grandes metrópoles, de um lado, e descentralização da urbanização, de outro, com aumento expressivo da proporção da população vivendo em cidades de 20 mil habitantes ou mais. É o que o autor denominou assimetria do processo de urbanização.

15. Fonte: Ipeadata (www.ipeadata.gov.br/ipeaweb.dll/ipeadata?6175015).

16. Nos anos 1990, entram em cena no Brasil programas de transferência de renda a famílias pobres, como o Bolsa Escola, do governo de Fernando Henrique Cardoso, e o Bolsa Família, do governo de Luiz Inácio Lula da Silva, esse último atingindo 40 milhões de pessoas em 2006.

17. Dados em Singer (1981:66).

18. O curioso é que, no campo, essa última agregação englobava $75,8 \%$ dos empregados (é verdade que 50\% ganhavam até um salário mínimo, contra um quarto dos trabalhadores urbanos).

19. Trinta e seis por cento ganhavam menos de $R \$ 360$, reflexo da estagnação do processo de melhoria dos indicadores de renda no país.

20. Dados de 1980 extraídos do Anuário Estatístico do Brasil, vol. 44 (IBGE, 1984). Fonte dos dados de 2000: IBGE (ftp://ftp.ibge.gov.br/Censos/Censo_Demografico_ 2000/trabalho_rendimento/Brasil/Brasil.zip). 
21. A mobilidade geral, medida em termos de classe social, foi muito alta, como mostraram Pastore e Silva (2000) e Scalon (1999). Refiro-me à mobilidade de renda, esta, sim, muito baixa no período.

22. Para essa definição de baixa renda, ver McKnight (2008).

23. Para se chegar a esse resultado, as ocupações dos chefes de família foram ordenadas segundo a renda média, e aquelas com remuneração igual ou inferior a $60 \%$ da média total dos ocupados foram definidas como "de baixa renda". Essa definição foi aplicada também às ocupações dos pais.

24. Informação computada a partir das bases de dados originais.

25. Dados do censo de 1970, publicados no Anuário Estatístico do Brasil, vol. 32 (IBGE, 1971).

26. Dados referentes ao Censo Demográfico de 1980, publicados no Anuário Estatístico do Brasil, vol. 44 (IBGE, 1984).

27. Tabulado a partir dos microdados da PNAD (2001).

28. Reconstituição recente da inércia social brasileira, que ganha estatuto de conceito em um coerente argumento sobre a persistente desigualdade no Brasil, foi feita por Santos (2006). Explicações para o moroso processo de transição escolar podem ser encontradas em Hasenbalg e Silva (2000), que atribuem a melhoria nos anos 1990 sobretudo à transição demográfica, portanto, e nos termos deste capítulo, à história lenta dos movimentos populacionais. Ver ainda Soares, Carvalho e Kipnis (2003).

29. Sobre isso, ver Dubar (2005). Além da trajetória via sistema escolar, na França e na Alemanha, foi importante também a cultura comunitarista dos ofícios, cujo saber era passado de pai para filho ou de mestre para aprendiz em mercados fechados e previsíveis. Ver Reynaud (1989). A seqüência de eventos mencionada, do nascimento ao casamento, expressa uma parte do curso de vida das pessoas, objeto de vasta literatura especializada, cujas linhas gerais podem ser encontradas, entre muitos outros, em Elder Jr. (1985).

30. Granovetter $(1974 ; 1988)$ discute os problemas e os limites dessa concepção.

31. Ver Crouch (1999), que se refere a esse processo como parte do "compromisso de meados do século" que sustentou os Estados de Bem-Estar europeus.

32. A referência aqui é a Escola Francesa da Regulação, em especial o clássico de Aglietta (1997).

33. O relatório da OECD (2000) classifica o programa de aprendizagem como um terceiro tipo de sistema educacional, em que o jovem pode escolher entre a educação generalista ou um período de experiência relativamente longo dentro das empresas. $\mathrm{O}$ programa também é chamado de sistema dual (dual system vocational training), em que pouco ou nenhum tempo é despendido na escola, diferentemente do ensino vocacional, no qual o treinamento é organizado pela escola (school-based vocational training). Ver também Wolbers (2003).

34. Os regimes menos competitivos são, em geral, caracterizados por alta proporção de educação vocacional específica (ensino técnico e profissionalizante), enquanto nos regimes abertos a educação tende a ser predominantemente acadêmica, ou geral, de modo que as habilidades ocupacionais são adquiridas no trabalho ou em cursos profissionalizantes pós-escolarização formal (Müller e Shavit, 1998). O Brasil contemporâneo está mais próximo desse segundo modelo (Hasenbalg, 2003:149). 
35. Na França, no auge da "sociedade salarial", perto de $90 \%$ da população se inseria como assalariada no mercado de trabalho (Castel, 1998). Alemanha, Inglaterra, Estados Unidos e Japão são casos semelhantes.

36. Esse cálculo exclui os que não estudavam nem trabalhavam. Conto apenas os que, tendo deixado a escola, estavam empregados ou procurando emprego.

37. O ápice da ocupação industrial ocorreu em 1983, com $25 \%$ da população empregada. Dado em Sabóia (1995:1130).

38. Informação gerada a partir dos microdados da PNAD (1976).

39. Em 1980, esses valores eram $88 \%$ e $68 \%$, respectivamente. Para uma análise convergente sobre as mudanças nos anos 1990, ver Camarano et alii (2001).

40. Sobre a depreciação das credenciais educacionais nos anos 1990 e 2000, ver Silva (2003), Hasenbalg (2003), Camarano et alii (2004) e Torche e Costa Ribeiro (2007).

41. Exceções importantes foram a Alemanha e a Áustria. No primeiro país, a taxa de participação das mulheres na força de trabalho foi de 44\% em 1960; no segundo, de 57\%. Ver Crouch (1999:428-429). A idade média do primeiro casamento para as mulheres, em dezoito países avançados, era de 23,8 anos em 1960, com mínima de 20,3 anos nos Estados Unidos e máxima de 27,1 na Irlanda (ibidem:460).

42. Dados em Costa Ribeiro (2007:311). Essa proporção era equivalente à encontrada em Portugal e na Espanha, os países mais pobres da Europa no mesmo ano. Ver Crouch (1999:430-431).

43. A taxa dos homens volta a ultrapassar a das mulheres aos 18 anos de idade.

44. Tomando-se as jovens de 16 anos, por exemplo, 40\% delas estudavam em 1970 (somando-se as que também trabalhavam). Em 1980, a proporção era de 46\%; em 1991, $58 \%$; em 2000, de 67,4\%. Entre os homens, as taxas foram, respectivamente, $44 \%$, 49\%, $52,5 \%$ e $66,2 \%$.

45. Segundo a PNAD de 1976, 17,4\% das mulheres de 18 anos já haviam experimentado um primeiro casamento. Entre as de 22 anos, a taxa era de $49,8 \%$ (23\% entre os homens).

46. Como era comum dizer, na sociologia brasileira nos anos 1960, o processo de urbanização foi muito mais intenso do que o processo de industrialização (sinônimo, na época, de modernidade), o que obrigou uma proporção sempre crescente da força de trabalho a empregar-se nos setores informais da economia. Ver Lopes (1971a; 1971b) e Kowarick (1974). Faria (1991) é uma crítica.

47. Como mostra Costa Ribeiro (2007:75), em 1996, ainda tínhamos 60\% da PEA composta de filhos e filhas de pessoas com origem rural.

48. Dados tabulados diretamente da PNAD (1982).

49. Para a construção da tabela, a informação sobre posição na ocupação foi ajustada, já que, nos anos 1990, a PNAD incluiu as categorias "trabalhador na produção para o próprio consumo" e "trabalhador na construção para o próprio uso". Foi considerada também apenas a informação sobre ocupados na semana de referência.

50. O índice de dissimilaridade é o mesmo utilizado mais adiante, ou seja, D=( | P2005 P1976 I ) / P1976*100.

51. Tal como definida por Boyer (1990), isto é, sustentada por alta divisão do trabalho e fragmentação de tarefas de produção, demandando trabalho pouco ou nada qualifi- 


\section{Adalberto Cardoso}

cado, remunerado segundo parâmetros mínimos definidos no âmbito de políticas do Estado de Bem-Estar, garantidor do pleno emprego e da renda no desemprego.

52. No Brasil, o seguro-desemprego pode durar de três a seis meses, dependendo do tempo em que o demandante tenha estado empregado nos últimos 36 meses, mas o tempo médio de procura de trabalho em 2002, segundo a Pesquisa Mensal de Emprego - PME, era de 23 semanas, ou quase seis meses. Dados gerados em www. sidra.ibge.gov.br.

53. Em 1976, a PNAD coletou informação sobre tempo no emprego, mas apenas para uma parcela da amostra, o que não permite comparações no tempo. Em 1992, a pergunta sobre há quanto tempo está no emprego atual passou a figurar no questionário padrão da PNAD.

54. Defini o recorte para pessoas de 25 anos ou mais porque, como será visto, nessa idade, as probabilidades de percurso ocupacional das pessoas já estão praticamente definidas.

55. Ver também Guimarães (2007).

56. Analiso apenas as trajetórias de homens, por questões de espaço, mas ciente de que a dinâmica geral é diferente segundo o sexo.

57. A rigor, os gráficos para os jovens com oito anos ou menos de escolaridade poderiam começar aos dez anos de idade. Contudo, isso os tornaria não-comparáveis aos gráficos daqueles que tinham onze anos de estudo ou mais, já que a primeira idade em que os dados para esse estrato se tornam estatisticamente significativos (isto é, com número suficiente de casos para separar por sexo, anos de estudo e classe social) é 18 anos.

58. Ver Costa Ribeiro (2007).

59. Optei por apresentar os dados para o total dos jovens com onze anos ou mais de escolaridade para assegurar uma descrição de trajetória a partir dos 18 anos. Se apresentasse os percursos dos graduados, estatísticas significativas segundo a classe social só têm início aos 22 anos, e os gráficos cobririam apenas quatro anos de suas vidas, impedindo análises mais aprofundadas.

60. Pessoas com quinze anos de estudo ou mais eram 4,7\% do total em 2005, contra 3,9\% em 1995, segundo a PNAD.

61. Trata-se de um índice de dissimilaridade composto pela média das diferenças entre as probabilidades de classe aos 30 e aos 20 anos de idade: D=Média ( | P30 - P20 | / P20)*100.

62. Os aposentados tornam incomparáveis as taxas de jovens e da população total, porque os jovens, por definição, não chegaram à idade de se aposentar. Por isso, na comparação, é preciso excluir os inativos. O índice de dissimilaridade é o mesmo de antes: D=Média ( | P25 - PPEA | / PPEA)*100, em que PPEA é a probabilidade de cada posição de classe na PEA, e P25 é a probabilidade de cada posição aos 25 anos.

63. É preciso evitar equívoco comum, nesse tipo de análise, de atribuir, por exemplo, aos jovens de 25 anos, hoje, a mesma probabilidade de destino dos jovens que têm 30 anos, como se a probabilidade destes, atual, fosse a mesma daqueles daqui a cinco anos. É claro que a estrutura social apresenta grande inércia estrutural, porque é construída com base nas ocupações e o mercado de trabalho muda muito lentamente. No entanto, em dois anos, muita coisa pode acontecer, como uma crise econômica 
que aumente o desemprego ou, ao contrário, que gere novas posições em setores emergentes da economia, mudando as probabilidades tanto dos mais quanto dos menos escolarizados. Por isso, o que se disse deve ser tomado como a probabilidade de destino no futuro se o mercado de trabalho permanecer, em 2010, como estava em 2005.

64. O fato de ainda necessitarmos de políticas públicas de incentivo para que as famílias pobres mantenham suas crianças na escola é um indicador de que as barreiras econômicas à escolarização ainda permanecem ativas.

65. O tema não foi analisado aqui, mas é amplamente caracterizado em Hasenbalg e Silva (2003).

66. De fato, a média de anos de estudo dos jovens de 25 anos nascidos em 1956 (portanto, captada pela PNAD de 1981) e que estavam nas classes superiores era de 11,3. Nas classes médias urbanas, era de 9,7 anos. Para os jovens na mesma idade nascidos em 1980, os valores tinham saltado para 13,2 e 11,5, respectivamente. O mais importante, porém, é que também nas classes baixas urbanas o aumento na média de anos de estudo foi expressivo, de 5,4 anos para a coorte de 1956 para 9,2 anos no caso da coorte de 1980. A fonte é a mesma PNAD, nos anos de 1981 e 2005.

\section{REFERÊNCIAS BIBLIOGRÁFICAS}

AGLIETTA, Michel. (1997), Régulation et Crises du Capitalisme. Paris, Odille Jacob. (Col. Oppus).

ANDRADE, Gladys. (2005), “O Programa Nacional de Estímulo ao Primeiro Emprego de Jovens". Mercado de Trabalho: Conjuntura e Análise, vol. 10, no 26, pp. 3-5. Disponível em www.ipea.gov.br/pub/bcmt/mt_26c.pdf.

APPY, Bernard. (1993), "Questão Fiscal: Crise e Concentração de Renda”, in B. Appy et alii (orgs.), Crise Brasileira, Anos Oitenta e Governo Collor. São Paulo, DESEP/CUT, pp. 7-82.

BIELSCHOWSKY, Ricardo. (1996), Pensamento Econômico Brasileiro: O Ciclo Ideológico do Desenvolvimentismo (3a ed.). Rio de Janeiro, Contraponto.

BIER, Amaury G. et alii. (1988), “O Desenvolvimento em Xeque: Estado e Padrão de Financiamento no Brasil", in L. Sola (org.), O Estado da Transição: Política e Economia na Nova República. São Paulo, Vértice.

BOLTANSKI, Luc e CHIAPELLO, Ève. (2002), El Nuevo Espíritu del Capitalismo. Madrid, Ediciones Akal.

BOURDIEU, Pierre e PASSERON, Jean-Claude. (1974), A Reprodução: Elementos para uma Teoria do Sistema de Ensino. Rio de Janeiro, Francisco Alves.

BOYER, Robert. (1990), A Teoria da Regulação: Uma Análise Crítica. São Paulo, Nobel. 


\section{Adalberto Cardoso}

BRANT, Vinícius C. e SINGER, Paul. (1976), São Paulo 1975: Crescimento e Pobreza. São Paulo/Petrópolis, Cebrap/Vozes.

BRESSER-PEREIRA, Luiz Carlos. (1996), Crise Econômica e Reforma do Estado no Brasil. São Paulo, Editora 34.

CAMARANO, Ana Amélia et alii. (2001), “Os Jovens Brasileiros no Mercado de Trabalho". Mercado de Trabalho: Conjuntura e Análise, vol. 6, no 17, pp. 31-39. Disponível em www.ipea.gov.br.

CAMARANO, Ana Amélia et alii. (2003), “A Transição para a Vida Adulta: Novos ou Velhos Desafios?". Mercado de Trabalho: Conjuntura e Análise, vol. 8, no21, pp. 53-66. Disponível em www.ipea.gov.br.

CAMARANO, Ana Amélia et alii. (2004), “Caminhos para a Vida Adulta: As Múltiplas Trajetórias dos Jovens Brasileiros". Texto para Discussão, no 1038, Rio de Janeiro, Ipea. Disponível em www.ipea.gov.br.

CANO, Wilson. (2000), Soberania e Política Econômica na América Latina. São Paulo, Editora Unesp.

CARDOSO, Adalberto M. (2003), A Década Neoliberal e a Crise dos Sindicatos no Brasil. São Paulo, Boitempo.

CASTEL, Robert. (1998), As Metamorfoses da Questão Social: Uma Crônica do Salário. Petrópolis, Vozes.

CORSEUIL, Carlos H., SANTOS, Daniel e FOGUEL, Miguel. (2001), “Decisões Críticas em Idades Críticas: A Escolha dos Jovens entre Estudo e Trabalho no Brasil e em outros Países da América Latina". Texto para Discussão, no 797, Rio de Janeiro, Ipea.

COSTA RIBEIRO, Carlos Antônio. (2007), Estrutura de Classe e Mobilidade Social no Brasil. Bauru/São Paulo, Edusc/Anpocs.

CROUCH, Colin. (1999), Social Change in Western Europe. Oxford, Oxford University Press.

DUBAR, Claude. (2005) [1991], A Socialização: Construção das Identidades Sociais e Profissionais. São Paulo, Martins Fontes.

ELDER JR., Glen H. (org.). (1985), Life Course Dynamics: Trajectories and Transitions, 1968-1980. Ithaca/London, Cornell University Press.

FARIA, Vilmar E. (1983), “Desenvolvimento, Urbanização e Mudança na Estrutura do Emprego: A Experiência Brasileira", in B. Sorj e M. H. T. de Almeida (orgs.), Sociedade e Política no Brasil Pós-64. São Paulo, Brasiliense.

. (1991), “Cinqüenta Anos de Urbanização no Brasil”. Novos Estudos Cebrap, no 29, pp. $98-119$.

FURTADO, Celso. (1961), Desenvolvimento e Subdesenvolvimento. Rio de Janeiro, Fundo de Cultura.

(1966), Subdesenvolvimento e Estagnação na América Latina. Rio de Janeiro, Paz e Terra.

(1974), O Mito do Desenvolvimento Econômico. Rio de Janeiro, Paz e Terra. 
GOUVEIA, Aparecida J. (1989), “As Ciências Sociais no Brasil e a Pesquisa sobre Educação". Tempo Social, vol. 1, no 1, pp. 71-79.

GRANOVETTER, Mark S. (1974), Getting a Job: A Study of Contacts and Careers. Cambridge, Cambridge University Press.

. (1988), “The Sociological and Economic Approaches to Labor Market Analysis: A Social Structural View", in G. Farkas e P. England (eds.), Industries, Firms and Jobs: Sociological and Economic Approaches. New York, Plenum Press, pp. 187-216.

GUIMARÃES, Nadya. (2007), “Trajetórias Inseguras, Autonomização Incerta: Os Jovens e o Trabalho em Mercados sob Intensas Transições Ocupacionais". Disponível em www.centrodametropole.org.br/pdf/2007/nadya_03.pdf, acessado em julho de 2007.

HARVEY, David. (1992), A Condição Pós-Moderna. São Paulo, Edições Loyola.

HASENBALG, Carlos. (2003), "A Transição da Escola para o Trabalho", in C. Hasenbalg e N. do V. Silva (orgs.), Origens e Destinos. Desigualdades Sociais ao Longo da Vida. Rio de Janeiro, Topbooks, pp. 147-172.

e SILVA, Nelson do Valle. (2000), “Tendências das Desigualdades Educacionais no Brasil". DADOS, vol. 43, no 3, pp. 423-445.

(orgs.). (2003), Origens e Destinos: Desigualdades Sociais ao Longo da Vida. Rio de Janeiro, Topbooks.

IBGE - INSTITUTO BRASILEIRO DE GEOGRAFIA E ESTATÍSTICA. (1990), Estatísticas Históricas do Brasil (2a ed. rev.). Rio de Janeiro, IBGE, vol. 3. (Série Estatísticas Retrospectivas).

. (2003), Estatísticas do Século XX. Rio de Janeiro, IBGE. . (vários anos), Anuário Estatístico do Brasil. Rio de Janeiro, IBGE.

KERCKHOFF, Alan C. (1990), Getting Started: Transitions to Adulthood in Great Britain. Boulder, Westview Press.

KOWARICK, Lucio. (1974), Capitalismo e Marginalidade da América Latina. Rio de Janeiro, Paz e Terra

KUPFER, David, FERRAZ, João Carlos e IOOTTY, Mariana. (2003), “Made in Brazil: Industrial Competitiveness Ten Years after Economic Liberalization". Latin American Studies Series, vol. 4, pp. 32-85.

LOPES, Juarez B. (1971a), Sociedade Industrial no Brasil. São Paulo, Difusão Européia do Livro.

. (1971b), Desenvolvimento e Mudança Social: Formação da Sociedade Urbano-Industrial no Brasil. São Paulo, Nacional.

MCKNIGHT, Abigail. (2008), “Mobilidade de Baixa Renda numa Perspectiva de Trajetória de Vida Ocupacional”, in N. Guimarães, A. Cardoso, P. Elias e K. Purcell (orgs.), Mercados de Trabalho e Oportunidades. Reestruturação Econômica, Mudança Ocupacional e Desigualdade no Brasil e na Grã-Bretanha. Rio de Janeiro, Editora FGV.

MÜLLER, Walter e GANGL, Markus. (2003), "The Transition from School to Work: An European Perspective", in W. Müller e M. Gangl (eds.), Transitions from Education to Work in Europe. Oxford, Oxford Scholarship Online, pp. 1-21. 


\section{Adalberto Cardoso}

MÜLLER, Walter e SHAVIT, Yossi. (1998), From School to Work. A Comparative Study of Educational Qualifications and Occupational Destinations. Oxford, Clarendon Press.

OECD - ORGANISATION FOR ECONOMIC CO-OPERATION DEVELOPMENT. (2007), The World Economy. Historical Statistics. Disponível em www.theworldeconomy. org/ publications/worldeconomy, acessado em julho de 2007.

OLIVEIRA, Francisco de. (1972), “A Economia Brasileira: Crítica à Razão Dualista”. Estudos Cebrap, no 2. São Paulo, Editora Brasileira de Ciências.

PACHECO, Carlos Américo. (1999), “Novos Padrões de Localização Industrial? Tendências Recentes dos indicadores da Produção e do Investimento Industrial". Texto para Discussão, no 633, Brasília, Ipea.

PASTORE, José e SILVA, Nelson do Valle. (2000), Mobilidade Social no Brasil. São Paulo, Makron Books.

PINÇON, Michel. (1987), Désarrois Ouvriers. Familles de Métallurgistes dans les Mutations Industrielles et Sociales. Paris, L'Harmattan.

PRANDI, Reginaldo. (1978), O Trabalhador por Conta Própria sob o Capital. São Paulo, Símbolo.

. (1982), Os Favoritos Degradados: Ensino Superior e Profissões de Nível Universitário no Brasil de Hoje. São Paulo, Edições Loyola.

REYNAUD, Jean-Daniel. (1989), Les Règles du Jeu: Action Collective et Régulation Sociale. Paris, A. Colin.

ROCHA, Sonia. (2003), Pobreza no Brasil. Afinal, do que se Trata? Rio de Janeiro, Editora FGV.

ROSENBAUM, James E. e KARIYA, Takehiko. (1989), "From High School to Work: Market and Institutional Mechanisms in Japan". American Journal of Sociology, vol. 94, no 6, pp. 1334-1365.

ROULLEAU-BERGER, Laurence e GAUTHIER, Madeleine. (2001), Les Jeunes et L'Emploi dans les Villes D'Europe e D'Amérique du Nord. Paris, Éditions de L'Aube.

SABÓIA, João. (1995), “Mercado de Trabalho no Brasil - Evolução e Tendências Recentes". Anais do Encontro Nacional de Estudos do Trabalho (vol. III), São Paulo, ABET, pp. 1123-1148.

. (1999), “Um Novo Índice para o Mercado de Trabalho Urbano no Brasil”. Anais do VI Encontro Nacional de Estudos do Trabalho. Belo Horizonte, 6-8 de outubro, pp. 455-478.

SCALON, Maria Celi. (1999), Mobilidade Social no Brasil: Padrões e Tendências. Rio de Janeiro, Revan.

SHAVIT, Yossi e BLOSSFELD, Hans Peter (orgs.). (1993), Persistent Inequality: Changing Educational Attainment in Thirteen Countries. Bolder, Westview.

SILVA, Nelson do Valle. (2003), "Expansão Escolar e Estratificação Educacional no Brasil", in C. Hasenbalg e N. V. Silva (orgs.), Origens e Destinos: Desigualdades Sociais ao Longo da Vida. Rio de Janeiro, Topbooks, pp. 105-146.

SINGER, Paul. (1981), Dominação e Desigualdade: Estrutura de Classes e Repartição da Renda no Brasil. São Paulo, Paz e Terra. 
(1988), "Reflexões sobre Inflação, Conflito Distributivo e Democracia", in F. W. Reis e G. O'Donnell (orgs.), Democracia no Brasil: Dilemas e Perspectivas. São Paulo, Vértice.

SOARES, Serguei, CARVALHO, Luiza e KIPNIS, Bernardo. (2003), “Os Jovens Adultos de 18 a 25 Anos: Retrato de uma Dívida da Política Educacional". Texto para Discussão, no 954, Rio de Janeiro, Ipea.

TARTUCE, Gisela Pereira. (2007), Tensões e Intenções na Transição Escola-Trabalho: Um Estudo das Vivências e Percepções de Jovens sobre os Processos de Qualificação Profissional e (Re)Inserção no Mercado de Trabalho na Cidade de São Paulo. Tese de doutorado em Sociologia, USP, São Paulo.

TORCHE, Florencia e COSTA RIBEIRO, Carlos Antônio. (2007), Educational Expansion and Decline in the "Mobility Returns" of Higher Education: The Case of Brazil and Mexico. Trabalho apresentado no Encontro Social Inequality and Mobility in the Process of Social Transformation. Brno Czech Republic, 24-27 de maio.

WOLBERS, Maarten H. J. (2003), “Learning and Working: Double Statuses in Youth Transitions", in W. Müller e M. Gangl (orgs.), Transitions from Education to Work in Europe. Oxford, Oxford Scholarship Online, pp. 131-156. 


\section{ABSTRACT \\ Transitions from School to Work in Brazil: The Persistence of Inequality and Frustrated Expectations}

This study analyzes the changes in economic structure and labor markets in the last 60 years in Brazil that provided the basis for establishing patterns in the transition from school to work for young men and women born since 1948. Data from population censuses beginning in 1970 and the National Household Sample Surveys (PNADs) beginning in 1976 were used to support the idea that Brazil witnessed a developmentalist pattern in the social trajectories of young people marked by lesser importance of education in shaping their initial life opportunities, constructed in a highly unstable and poorly structured labor market. This pattern can be distinguished from another, which we will call a fordist transition pattern, typical of advanced capitalist countries and characterized by strong family and state control over the general work qualifications processes, in which the school plays a central role and serves as the principal element for social mobility and creation of life opportunities.

Key words: transition from school to work; social mobility; social inequality; work market; social structure

\section{RÉSUMÉ}

Transitions de l'École vers le Travail au Brésil: Persistance des Inégalités et Frustration des Attentes

Dans ce travail on étudie les changements dans la structure économique et dans les marchés du travail au long de 60 annnées au Brésil: ces changements ont jalonné la construction de modèles de transition de l'école vers le travail pour des jeunes gens des deux sexes nés à partir de 1948. On se sert de données de recensements démographiques depuis 1970 ainsi que des PNADs depuis 1976 pour montrer que, au Brésil, il s'est formé un modèle de développement de la trajectoire sociale des jeunes où l'on remarque le peu d'importance donnée à l'éducation pour leurs premières chances de travail, construites dans un marché hautement instable et peu structuré. Ce modèle peut se distanguer d'un autre, appelé le modèle fordiste de transition, propre aux pays à capitalisme avancé et marqué par un contrôle étroit issu des familles ainsi que de l'État, sur les processus généraux de qualification au travail, dans lesquels l'école a eu une place centrale, en tant que principal élément de mobilité sociale et de production de chances dans la vie.

Mots-clé: transition école-travail; mobilité sociale; inégalités sociales; marché du travail; structure sociale 